\title{
1 Diagnostic Cerebrospinal Fluid Biomarker Discovery and Validation in 2 Patients with Central Nervous System Infections
}

3 Tran Tan Thanh ${ }^{1 \dagger}$, Climent Casals-Pascual ${ }^{2 \dagger}$, Nguyen Thi Han $\mathrm{Ny}^{1}$, Nghiem My Ngoc, Ronald 4 Geskus ${ }^{1}$,Le Nguyen Truc Nhu ${ }^{1}$, Nguyen Thi Thu Hong ${ }^{1}$, Du Trong Duc ${ }^{3}$, Do Dang Anh Thu ${ }^{1}$, 5 Phan Nha Uyen ${ }^{1, \#}$, Vuong Bao Ngoc ${ }^{1, * *}$, Le Thi My Chau ${ }^{4}$, Van Xuan Quynh ${ }^{4}$, Nguyen Ho Hong 6 Hanh $^{5}$, Nguyen Thuy Thuong Thuong ${ }^{1}$, Le Thi Diem ${ }^{5}$, Bui Thi Bich Hanh ${ }^{3}$, Vu Thi Ty Hang ${ }^{1}$, 7 Pham Kieu Nguyet Oanh ${ }^{4}$, Roman Fischer ${ }^{6,7}$, Nguyen Hoan Phu ${ }^{1,5}$, Ho Dang Trung Nghia ${ }^{1,3,4}$,

8 Nguyen Van Vinh Chau ${ }^{4}$, Ngo Thi Hoa ${ }^{1}$, Benedikt M. Kessler ${ }^{6,7}$, Guy Thwaites ${ }^{1,8}$, and Le Van $9 \operatorname{Tan}^{1 *}$

10 Affiliations:

$11{ }^{1}$ Oxford University Clinical Research Unit, Ho Chi Minh City, Vietnam.

12 2Department of Clinical Microbiology, Hospital Clínic de Barcelona, CDB; ISGlobal, Barcelona, 13 Institute for Global health, Barcelona, Spain

$14{ }^{3}$ Department of infectious diseases, Pham Ngoc Thach University of Medicine, Ho Chi Minh

15 City, Vietnam

$16{ }^{4}$ Hospital for Tropical Diseases, Ho Chi Minh City, Vietnam

$17{ }^{5}$ Department of Medicine, Vietnam National University, Ho Chi Minh City, Vietnam

$18{ }^{6}$ Target Discovery Institute, Nuffield Department of Medicine, University of Oxford, Oxford,

19 United Kingdom

$20{ }^{7}$ University of Oxford, Oxford, United Kingdom

$21{ }^{8}$ Centre for Tropical Medicine and Global Health, Nuffield Department of Medicine, University

22 of Oxford, Oxford, UK

23 Current affiliations: "Duy Tan University, Da Nang, Vietnam, **Taleed Academy, Ho Chi Minh

24 City, Vietnam

25 *To whom correspondence should be addressed: tanlv@ oucru.org

26 Authors contributed equally to this work.

27 Word counts: Abstract: 245, text: 2870

28 Keywords: Meningitis, central nervous system infections, mass-spectrometry, lipocalin 2,

29 biomarkers

30 Running title: Diagnostic biomarker discovery in central nervous system infected patients 


\section{ABSTRACT}

2 Background: Central nervous system (CNS) infections are common causes of morbidity and

3 mortality worldwide. Rapid, accurate identification of the likely cause is essential for clinical

4 management and the early initiation of antimicrobial therapy, which potentially improves clinical

5 outcome.

6 Methods: We applied liquid chromatography tandem mass-spectrometry on 45 cerebrospinal

7 fluid (CSF) samples from a cohort of adults with/without CNS infections to discover potential

8 diagnostic protein biomarkers. We then validated the diagnostic performance of a selected

9 biomarker candidate in an independent cohort of 364 consecutively treated adults with CNS

10 infections admitted to a referral hospital in southern Vietnam.

11 Results: In the discovery cohort, we identified lipocalin 2 (LCN2) as a potential biomarker of

12 bacterial meningitis. The analysis of the validation cohort showed that LCN2 could discriminate

13 bacterial meningitis from other CNS infections, including tuberculous meningitis, cryptococcal

14 meningitis and viral/antibody-mediated encephalitis (sensitivity: 0.88 (95\% confident interval

15 (CI): 0.77-0.94), specificity: 0.91 (95\%CI: 0.88-0.94) and diagnostic odd ratio: 73.8 (95\%CI:

16 31.8-171.4)). LCN2 outperformed other CSF markers (leukocytes, glucose, protein and lactate)

17 commonly used in routine care worldwide. The combination of LCN2 and these four routine

18 CSF markers resulted in the highest diagnostic performance for bacterial meningitis (area under

19 receiver-operating-characteristic-curve 0.96 ; 95\%CI: 0.93-0.99).

20 Conclusions: Our results suggest that LCN2 is a sensitive and specific biomarker for

21 discriminating bacterial meningitis from a broad spectrum of CNS infections. A prospective

22 study is needed to further assess the diagnostic utility of LCN2 in the diagnosis and management

23 of CNS infections. 


\section{INTRODUCTION}

2 Central nervous system (CNS) infections cause significant mortality and morbidity worldwide,

3 but especially in low- and middle-income countries (1). Common CNS infections include

4 bacterial meningitis (BM), viral encephalitis, tuberculous meningitis (TBM) and cryptococcal

5 meningitis (2), but there are $>100$ documented infectious causes of CNS infections (3).

6 Additionally, over the last decade, antibody-mediated causes of encephalitis (e.g. anti-N-methyl-

7 D-aspartate receptor (anti-NMDAR) encephalitis) have been recognized (4), which further

8 challenges routine diagnostics.

9 Clinical features are often insufficient to discriminate the likely cause and standard laboratory

10 investigations identify the causative agent in $<60 \%$ of cases $(5,6)$. Critically, the clinical

11 management of CNS infections varies according to its aetiology. Thus, rapid and accurate

12 identification of the likely cause of the infection is essential to initiate appropriate therapy and

13 improve patient outcome.

14 Over the last decade, mass-spectrometry has emerged as a sensitive, hypothesis-free approach for

15 the discovery of novel diagnostic biomarkers in both communicable (e.g. CNS infections) and

16 non-communicable diseases (7-9). However, previous biomarker-discovery studies of CNS

17 infections have either been limited in sample size or have not included a validation phase (7).

18 Here, using a mass-spectrometry based approach we first searched for novel diagnostic

19 biomarkers in cerebrospinal fluid (CSF) samples from a discovery cohort of 45 patients with

20 brain infections. We then sought to validate our findings in an independent cohort of 364

21 consecutively treated adults with CNS infections. 


\section{MATERIALS AND METHODS}

\section{Setting and the clinical studies}

3 CSF samples were derived from three different clinical studies: study \#1, \#2 and \#3 (Figure 1),

4 conducted in the brain infections ward of the Hospital for Tropical Diseases (HTD) in Ho Chi

5 Minh City, Vietnam. HTD is a tertiary referral hospital for severe infectious diseases, including

6 suspected CNS infections, occurring in the southern provinces of Vietnam, with a population of

$7>40$ million.

8 The clinical study \#1 entitled "expanding the laboratory diagnosis of tuberculous meningitis and

9 meningoencephalitis in Vietnam" was conducted during January 2015-September 2016 (10). As

10 per the study protocol, any adult ( $\geq 18$ years) with a suspected CNS infection and requirement for

11 lumbar puncture was eligible for enrolment. Patients were excluded if pyogenic bacterial

12 meningitis (very cloudy or pus-like CSF) was suspected, lumbar puncture was contra-indicated,

13 or no informed consent was obtained.

14 The clinical study \#2 focused on the immunological responses in bacterial meningitis patients,

15 especially those infected with Streptococcus suis, and was conducted during 2015 and 2017. Any

16 patient ( $\geq 16$ years) with suspected pyogenic bacterial meningitis (very cloudy or pus-like CSF)

17 was eligible for enrolment. Patient was excluded if lumbar puncture was contra-indicated, or no

18 informed consent was obtained.

19 The clinical study \#3 started in September 2017 and is on-going. The study aims to explore the

20 potential diagnostic utility of next-generation sequencing and mass-spectrometry in CNS

21 infections. Any patient ( $\geq 16$ years) with suspected CNS infection and requirement for lumbar

22 puncture was eligible for enrolment. Patients were excluded if no written informed consent was

23 obtained. 
1 For all the aforementioned studies, CSF and plasma samples were collected at presentation

2 alongside demographic and clinical data and the results of routine diagnostic tests. All specimens

3 were stored at $-80^{\circ} \mathrm{C}$ until analysis.

\section{$4 \quad$ Routine diagnosis}

5 As part of routine care, CSF specimens of patients with suspected CNS infections were cultured

6 and/or examined by microscopy for the detection of bacteria, fungi and Mycobacterium

7 tuberculosis with the use of standard methods (Table S1) (11). Herpes simplex virus (HSV)

8 PCR was performed on CSF from those with suspected viral encephalitis. Varicella zoster virus

9 (VZV) PCR, and serological testing for dengue virus (DENV) IgM, Japanese encephalitis virus

10 (JEV) or mumps virus $(\mathrm{MuV})$ was performed if clinically indicated and when testing for other

11 pathogens was negative. Diagnosis of measles was based on compatible clinical features and the

12 presence of measles IgM.

\section{Assignment of CNS infection diagnosis}

14 Assignment of the CNS infection cause (TBM, BM, cryptococcal meningitis, eosinophilic

15 meningitis, or anti-NMDAR encephalitis) was first based on the results of standard laboratory

16 investigations. The diagnosis was confirmed if the relevant infectious agent was identified in the

17 CSF. Otherwise, patients were considered as having clinically suspected CNS infections

18 (TBM/BM/encephalitis) based on treatment responses and/or clinical judgment of treating

19 physicians. Because of the focus of the present study, probable and possible TBM (defined by

20 the Marais criteria (12)) were regarded as clinically suspected TBM. CNS infection was

21 excluded in those with no meningeal signs, CSF laboratory parameters were in normal ranges,

22 and all microbiological and serological investigations were negative. 


\section{Sample preparation and mass-spectrometry analysis}

2 CSF was analyzed as individual samples using proteomic platforms available at the Target

3 Discovery Institute, University of Oxford. Briefly, CSF was digested in solution after

4 reduction/alkylation with DTT/Iodoacetamide, followed by protein precipitation with

5 Chloroform/Methanol (13). After tryptic digest, peptides were desalted using SepPak C18

6 cartridges (Waters) and injected into a LC-MS/MS platform consisting of Dionex Ultimate3000

7 nHPLC (Thermo) and either Q-Exactive or Q-Exactive HF. Peptides were separated with a linear

8 gradient of 5-35\% Acetonitrile in $0.1 \%$ Formic acid over 60 minutes using a 50cm x $75 \mu \mathrm{m}$ Easy

9 Spray column (Thermo). MS1 resolution was set to 70,000 (HF 60,000) with an AGC target of

10 3E6. Fragment spectra were acquired with a resolution of 17,500 (HF 30,000) for up to $128 \mathrm{~ms}$

11 (HF 45ms) and an AGC target of 1E5 ions. The output data were searched for human proteome

12 (Uniprot, 05/2016 and 05/2018) using Mascot 2.5 or the Central Proteomics Pipeline (14).

13 Peptide FDR was adjusted to $1 \%$ and lable free quantitation was conducted with either SINQ

14 (15) within the CPFP or Progenesis QI version 3.1.4003.30577. Separation of CNS infection

15 diagnostic groups based on the obtained peptide/protein profiles was performed using Perseus

16 software version 1.6.6.0 (16)

\section{Measurement of lipocalin-2 concentration by quantitative ELISA}

18 Measurement of lipocalin 2 (LCN2) concentrations was performed on CSF samples of the

19 discovery and validation cohort as well as a subset of plasma samples of the validation cohort

20 using Quantikine ${ }^{\circledR}$ ELISA kits (R\&D Systems, Minneapolis, MN, US). The experiments were

21 performed according to the manufacturer's instruction.

\section{Statistical analysis}


1 Continuous variables were compared using the Mann-Whitney $U$ test or the Kruskal-Wallis test

2 or Wilcoxon signed-rank test. The correlation between continuous variables was assessed using

3 Spearman correlation test. All statistical tests were performed two-sided. The area under the

4 receiver operating characteristic curve (AUROC) was used to quantify the diagnostic

5 performance of biomarkers for a given diagnosis. The cutoff values for outcome prediction were

6 selected based on the highest sum of sensitivity and specificity. A logistic regression model was

7 used to evaluate the diagnostic performance of two or more variables combined. All continuous

8 variables were modeled as linear terms. All analyses were performed in SPSS V23.0 (IBM Corp,

9 NY, US), and all figures were generated using GraphPad PRISM ${ }^{\circledR}$ V5.04 (GraphPad Software

10 Inc, CA, US).

\section{Ethics}

12 The study was approved by Institutional Review Board of HTD and the Oxford Tropical

13 Research Ethics Committee (OxTREC). Written informed consents were obtained from each

14 participant or a relative if the patient was incapacitated. 


\section{RESULTS}

\section{Baseline characteristics of the study population}

3 Discovery cohort: For the initial mass-spectrometry analysis, we selected a total of 45 patients

4 enrolled in the clinical study \#1 and \#2. This consisted of 40 patients with laboratory confirmed

5 CNS infections: TBM $(n=20), B M(n=10)$, encephalitis $(n=10)$, and five patients with non-CNS

6 infection (Figure 1). Of the 10 patients with BM, seven were infected with S. suis and three with

7 S. pneumoniae. Of the patients with encephalitis, herpes simplex virus was the cause in 5,

8 DENV in 3, JEV in 1 and mumps virus in 1. The cohort's clinical characteristics and outcomes

9 are presented in Table S2.

10 Validation cohort: To validate the results of the discovery phase, we selected 364 consecutive

11 adult patients enrolled in the study \#3 (Figure 1). The baseline characteristics, clinical outcomes,

12 and results of etiological investigations of the cohort are presented in Table S2 and the footnote

13 of Figure 1, respectively. After the exclusion of 43 patients without CNS infections, the etiology

14 was confirmed in $63 \%$ of the 321 patients with CNS infections. TBM was the most frequent

15 diagnosis, followed by viral encephalitis and BM. The remaining patients included those with

16 anti-NMDAR encephalitis, cryptococcal meningitis, parasitic eosinophilic meningitis and

17 neurotoxoplasmosis (Figure 1). Of the patients with TBM, BM and viral encephalitis, a

18 confirmed diagnosis was established in 97/122 (80\%), 44/64 (69\%) and 29/92 (32\%),

19 respectively. Of the 44 laboratory-confirmed bacterial meningitis patients, $S$. suis, was the

20 commonest cause $(\mathrm{n}=20)$, followed by $S$. pneumoniae $(\mathrm{n}=6)$ and Escherichia coli $(\mathrm{n}=5)$. Of the

2129 patients with laboratory confirmed viral encephalitis, HSV was the commonest cause $(\mathrm{n}=11)$,

22 followed by VZV (n=7), and DENV (n=5) (Figure. 1). 


\section{Biomarker discovery}

2 Tandem mass-spectrometry analysis of 45 CSF samples of the discovery cohort identified a total

3 of 1,012 proteins. Of these, 891 were included in the analysis based on the number of peptides

4 and sequence coverage. Subsequent analysis identified a total of 729 quantifiable protein

5 signatures that were clinical-entity specific, especially for patients with BM (Figure 2A). Of

6 these, 60 and 19 were significantly expressed in the CSF of patients with BM and TBM,

7 respectively (Table S3). No diagnostic biomarker candidate was found in patients with viral

8 encephalitis.

9 Of the protein candidates identified in the BM group, lipocalin 2 (LCN2), also known as

10 neutrophil gelatinase-associated lipocalin, had a sensitivity of 1 (95\%CI: 0.73-1) and a

11 specificity of 0.89 (95\%CI: 0.74-0.95) for prediction of BM (AUROC: 0.97 [95\% confidence

12 interval [CI], 0.9-1]). Because of its known biological significance in bacterial infections (17-

13 19), previous reports of high concentrations in bacterial meningitis $(20,21)$, and the availability

14 of a quantitative ELISA assay, LCN2 was thus selected for further evaluation.

\section{LCN2 ELISA analysis to verify the results of original LC-MS/MS analysis}

16 In order to verify the mass-spectrometry findings, we performed quantitative ELISA analysis of

17 the 45 CSF samples used for the discovery phase. Subsequently, the result suggested that LCN2

18 concentration of $159 \mathrm{ng} / \mathrm{ml}$ or above could accurately distinguish BM from TBM, encephalitis

19 and non-CNS infections groups; AUROC curve: 0.97 (95\%CI: 0.92-1), corresponding to the

20 sensitivity of $1(95 \% \mathrm{CI}: 0.72-1)$ and the specificity of 0.86 (95\%CI: $0.71-0.94)$ (Figures $2 \mathrm{~B}$ and

21 2C). Thus, the diagnostic values of LCN2 based on the results of quantitative ELISA analysis

22 confirmed the original finding of LC-MS/MS analysis. 


\section{CSF LCN2 concentrations in the validation cohort}

2 LCN2 was quantified in the CSF of the 364 consecutively treated adults with CNS infections

3 enrolled in the study \#3 (Figure 1). The results showed that LCN2 concentrations were

4 significantly different amongst the diagnostic groups with the highest concentration observed in

5 the BM group (median: 778. $8 \mathrm{ng} / \mathrm{ml}$, range: $2.5-6566.3$ ), followed by TBM groups (median:

$6 \quad 86.3 \mathrm{ng} / \mathrm{ml}$, range: 1.1-723.4) (Figure 3A). In contrast, LCN2 was almost absent or detected at

7 very low levels in CSF of patients presenting with anti-NMDAR encephalitis (median: 0.9

$8 \mathrm{ng} / \mathrm{ml}$, range: $0.2-27.8$ ) or in those without CNS infection (median: $0.2 \mathrm{ng} / \mathrm{ml}$, range: $0.2-120.3$ )

9 (Figure S1). Of the patients with BM, CSF LCN2 levels were higher in those with a confirmed

10 diagnosis than in those without a bacteria identified (Figure S1), while the duration of illness at

11 enrolment was similar between the two groups (data not shown).

\section{Diagnostic performance of CSF LCN2}

13 Analysis of LCN2 concentrations obtained from the validation cohort demonstrated that LCN2

14 could accurately discriminate bacterial meningitis from other CNS infections with AUROC

15 curves ranging from 0.9 (for BM vs. TBM, LCN2 concentration cut-off: $365 \mathrm{ng} / \mathrm{ml}$ ) to 0.99 (BM

16 vs. other CNS infections (i.e. non-encephalitis or non-TBM), LCN2 concentration cut-off: 134

$17 \mathrm{ng} / \mathrm{ml}$ ) and a diagnostic odd ratio (DOR) of 44.8 or above (Figure 3B).

18 Currently, CSF parameters such as leukocytes, protein, lactate and glucose concentrations are

19 routinely used as diagnostic makers in the primary assessment of patients presenting with CNS

20 infections. We thus compared the diagnostic performance of LCN2 alone and in combination

21 with these markers.. 
1 LCN2 outperformed the existing biomarkers in discriminating between BM and other CNS

2 infections (including TBM and encephalitis) (Figures 4A and 4B). When LCN2 was combined

3 with leukocytes, protein, lactate and glucose concentrations in CSF, the diagnostic model

4 consisting of LCN2 and these four CSF parameters provided the highest discriminatory ability

5 for BM (Figure 4C). More specifically, in terms of discriminating between BM and all other

6 CNS infections, the predictive values for BM based on AUROC curves and DOR increased from

$7 \quad 0.94$ (95\%CI: $0.80-0.98)$ to 0.96 (95\%CI: 0.93-0.99), and 66.2 to 308.3 when LCN2 was added

8 to the CSF parameters based model (Figure 4C). Similar results were obtained when assessing

9 the utility of LCN2 in discriminating between BM and other specific clinical entities (TBM or

10 encephalitis) (Figure 4D and Figure S2). LCN2 did not, however, help distinguish confirmed

11 from suspected BM (Table S4).

\section{Association between CSF and plasma concentrations of LCN2}

13 LCN2 is a ubiquitous protein which can be found in bodily fluids of healthy individuals (22). We

14 assessed if plasma LCN2 can be a surrogate of CSF LCN2 in a subset of 22 patients with BM

15 (laboratory confirmed: $n=14$ and clinically suspected: $n=8$ ). Plasma LCN2 concentration was,

16 however, significantly lower than that of CSF; median: $147.9 \mathrm{ng} / \mathrm{ml}$, range: $33.7-194.8$ vs. CSF

17 LCN2: median: $472.1 \mathrm{ng} / \mathrm{ml}$, range: $15.7-3102.3, \mathrm{P}<0.001$. There was no correlation between

18 CSF and plasma LCN2 (Spearman R: 0.37, P=0.08), suggesting that LCN2 is intrathecally

19 produced in response to the bacterial invasion of the CNS. 


\section{DISCUSSION}

2 Here, using a mass-spectrometry-based approach, we initially identified LCN2 as a potential

3 diagnostic marker for BM. Additional validation work on an independent cohort showed that

$4 \quad$ LCN2 could accurately discriminate BM from other CNS infections. LCN2 also outperformed

5 existing BM diagnostic makers (CSF leukocytes, and protein, glucose and lactate concentrations)

6 that are currently used as part of routine care. A diagnostic model consisting of LCN2 and these

7 four CSF parameters gave the best diagnostic performance for BM. Our data thus suggest that

8 LCN2 can act as an independent diagnostic maker of BM alone or in combination with other

9 CSF parameters.

10 LCN2 is secreted by neutrophils, hepatocytes and renal tubular cells (23). It is encoded by LCN2

11 gene and is known to have antibacterial properties because of its ability to inhibit the bacterial

12 growth via the interference of bacterial iron uptake (23). LCN2 has recently been recognized as a

13 sensitive biomarker for the diagnosis of severe blood stream infection (24) and pneumonia

14 caused by $S$. pneumoniae (18). High concentrations of LCN2 in the CSF of patients with BM

15 have been previously reported $(20,21)$. However, previous studies only focused on quantifying

16 LCN2 concentrations in patients with confirmed BM and viral encephalitis and did not compare

17 the performance of LCN2 against commonly used CSF markers such as leukocytes, glucose,

18 protein and lactate. Our study was conducted in Vietnam and included patients with many

19 different CNS infections, including bacterial, fungal, tuberculous, viral and parasitic meningitis,

20 and anti-NMDAR encephalitis). Additionally, we also compared the diagnostic performance of

21 LCN2 against that of CSF markers commonly used as part of routine care worldwide. As such,

22 our results have expanded our knowledge about the relation between LCN2 and CNS infections, 
1 and for the first time provide strong evidence that LCN2 is a highly sensitive biomarker for

2 discriminating BM from a broad-spectrum of CNS infections.

3 The differences in CSF LCN2 levels between laboratory confirmed and clinically suspected BM

4 groups pointed to the association between the host responses and an on-going infection (i.e. the

5 presence of a bacterial pathogen in clinical samples at the time of collection). This is in

6 agreement with previous studies showing that the decrease of plasma LCN2 level was correlated

7 with the success of antibiotic treatment in patients with bacteremia (17). Collectively, CSF

8 LCN2 might also be a useful marker for treatment response assessment. Therefore, further

9 research should aim at defining the optimal cut-off of LCN2 concentrations that can be used to

10 inform the administration or withdrawal of antibiotics in patients with BM.

11 Our study has some of limitations. A part from LCN2, we did not explore the utility potential of

12 the other biomarker candidates identified in the discovery cohort (e.g. CSF cathelicidin for BM

13 (25)) detected by original mass-spectrometry analysis). Likewise, we did not assess the

14 diagnostic performance of LCN2 against and/or in combination newly proposed biomarkers for

15 CNS infections such as procalcitonin and heparin-binding protein for $\operatorname{BM}(7,9,26-28)$, and CSF

16 lipoarabinomannan for TBM (29). Additionally, we only focused our analysis on adults, leaving

17 the utility potential of LCN2 in pediatric CNS infections unknown.

18 In spite of these limitations, the strengths of our study include that it represents the largest and

19 most comprehensive mass-spectrometry-based biomarker discovery investigation focusing on

20 patients with various clinical entities of CNS infections to date (7). The study was also conducted

21 in Vietnam and therefore includes all the major infectious causes of CNS infections seen

22 globally. Additionally, because our study was conducted at a single major tertiary referral 
1 hospital, all routine diagnostic approaches and patient assessments were consistent over the

2 course of the study, thereby minimizing potential bias.

3 To summarize, our study showed for the first time that LCN2 is a highly sensitive biomarker for

4 accurate prediction of BM in adults, especially when used alongside other standard CSF

5 parameters. Prospective studies are needed to assess the utility potential of LCN2 in the

6 diagnosis and management of CNS infections, including children, and whether it can be used in

7 settings with limited laboratory capacity to improve outcomes from these devastating conditions. 


\section{REFERENCES}

1. Roth GA, Abate D, Abate KH, Abay SM, Abbafati C, Abbasi N, et al. Global, regional, and national age-sex-specific mortality for 282 causes of death in 195 countries and territories, 1980-2017: a systematic analysis for the Global Burden of Disease Study 2017. The Lancet. 2018;392(10159):1736-88.

2. Ziai WC, Lewin JJ, 3rd. Update in the diagnosis and management of central nervous system infections. Neurologic clinics. 2008;26(2):427-68, viii.

3. Dubot-Peres A, Mayxay M, Phetsouvanh R, Lee SJ, Rattanavong S, Vongsouvath M, et al. Management of Central Nervous System Infections, Vientiane, Laos, 2003-2011. Emerg Infect Dis. 2019;25(5):898-910.

4. $\quad$ Dalmau J, Graus F. Antibody-Mediated Encephalitis. N Engl J Med. 2018;378(9):840-51. 5. Granerod J, Ambrose HE, Davies NWS, Clewley JP, Walsh AL, Morgan D, et al. Causes of encephalitis and differences in their clinical presentations in England: a multicentre, population-based prospective study. The Lancet Infectious Diseases. 2010;10(12):835-44. 6. Glaser CA, Honarmand S, Anderson LJ, Schnurr DP, Forghani B, Cossen CK, et al. Beyond viruses: clinical profiles and etiologies associated with encephalitis. Clin Infect Dis. 2006;43(12):1565-77.

7. Bharucha T, Gangadharan B, Kumar A, de Lamballerie X, Newton PN, Winterberg M, et al. Mass spectrometry-based proteomic techniques to identify cerebrospinal fluid biomarkers for diagnosing suspected central nervous system infections. A systematic review. J Infect. 2019;79(5):407-18.

8. Geyer PE, Holdt LM, Teupser D, Mann M. Revisiting biomarker discovery by plasma proteomics. Mol Syst Biol. 2017;13(9):942.

9. Njunge JM, Oyaro IN, Kibinge NK, Rono MK, Kariuki SM, Newton CR, et al. Cerebrospinal fluid markers to distinguish bacterial meningitis from cerebral malaria in children. Wellcome Open Res. 2017;2:47.

10. Heemskerk AD, Donovan J, Thu DDA, Marais S, Chaidir L, Dung VTM, et al. Improving the microbiological diagnosis of tuberculous meningitis: A prospective, international, multicentre comparison of conventional and modified Ziehl-Neelsen stain, GeneXpert, and culture of cerebrospinal fluid. J Infect. 2018;77(6):509-15.

11. Tan le V, Thai le H, Phu NH, Nghia HD, Chuong LV, Sinh DX, et al. Viral aetiology of central nervous system infections in adults admitted to a tertiary referral hospital in southern Vietnam over 12 years. PLoS Negl Trop Dis. 2014;8(8):e3127.

12. Marais S, Thwaites G, Schoeman JF, Torok ME, Misra UK, Prasad K, et al. Tuberculous meningitis: a uniform case definition for use in clinical research. The Lancet Infectious diseases. 2010;10(11):803-12.

13. Wessel D, Flugge UI. A method for the quantitative recovery of protein in dilute solution in the presence of detergents and lipids. Analytical biochemistry. 1984;138(1):141-3.

14. Trudgian DC, Thomas B, McGowan SJ, Kessler BM, Salek M, Acuto O. CPFP: a central proteomics facilities pipeline. Bioinformatics. 2010;26(8):1131-2.

15. Trudgian DC, Ridlova G, Fischer R, Mackeen MM, Ternette N, Acuto O, et al. Comparative evaluation of label-free SINQ normalized spectral index quantitation in the central proteomics facilities pipeline. Proteomics. 2011;11(14):2790-7. 
1 16. Tyanova S, Temu T, Sinitcyn P, Carlson A, Hein MY, Geiger T, et al. The Perseus computational platform for comprehensive analysis of (prote)omics data. Nat Methods. 2016;13(9):731-40.

4 17. Fjaertoft G, Foucard T, Xu S, Venge P. Human neutrophil lipocalin (HNL) as a diagnostic tool in children with acute infections: A study of the kinetics. Acta Paediatrica. 2005;94(6):661-6.

18. Huang H, Ideh RC, Gitau E, Thezenas ML, Jallow M, Ebruke B, et al. Discovery and validation of biomarkers to guide clinical management of pneumonia in African children. Clin Infect Dis. 2014;58(12):1707-15.

10 19. Venge P, Xu S. Diagnosis and Monitoring of Acute Infections with Emphasis on the

11 Novel Biomarker Human Neutrophil Lipocalin. J Appl Lab Med. 2019;3(4):664-74.

12 20. Guiddir T, Deghmane AE, Giorgini D, Taha MK. Lipocalin 2 in cerebrospinal fluid as a

13 marker of acute bacterial meningitis. BMC infectious diseases. 2014;14:276.

14 21. Lippi G, Avanzini P, Calzetti C, Caleffi A, Pipitone S, Musa R, et al. The role of neutrophil gelatinase-associated lipocalin (NGAL) in cerebrospinal fluids for screening of acute bacterial meningitis. Clinical laboratory. 2014;60(3):377-81.

17 22. Stejskal D, Karpisek M, Humenanska V, Hanulova Z, Stejskal P, Kusnierova P, et al.

18 Lipocalin-2: development, analytical characterization, and clinical testing of a new ELISA. Horm Metab Res. 2008;40(6):381-5. action of neutrophil gelatinase-associated lipocalin. J Am Soc Nephrol. 2007;18(2):407-13. 24. Herberg J, Huang H, Thezenas ML, Janes V, Carter M, Gormley S, et al. Lipocalin-2 is a Sensitive and Specific Marker of Bacterial Infection in Children. bioRiv. 2019.

25. Savonius O, Helve O, Roine I, Andersson S, Saukkoriipi A, Gonzalez Mata A, et al. Cerebrospinal Fluid Cathelicidin Correlates With the Bacterial Load and Outcomes in Childhood Bacterial Meningitis. Pediatr Infect Dis J. 2018;37(2):182-5.

26. Reshi Z, Nazir M, Wani W, Malik M, Iqbal J, Wajid S. Cerebrospinal fluid procalcitonin as a biomarker of bacterial meningitis in neonates. J Perinatol. 2017;37(8):927-31. 27. Li W, Sun X, Yuan F, Gao Q, Ma Y, Jiang Y, et al. Diagnostic Accuracy of Cerebrospinal Fluid Procalcitonin in Bacterial Meningitis Patients with Empiric Antibiotic

31 Pretreatment. J Clin Microbiol. 2017;55(4):1193-204.

32 28. Linder A, Akesson P, Brink M, Studahl M, Bjorck L, Christensson B. Heparin-binding

33 protein: a diagnostic marker of acute bacterial meningitis. Critical care medicine.

$34 \quad 2011 ; 39(4): 812-7$.

35 29. Siddiqi OK, Birbeck GL, Ghebremichael M, Mubanga E, Love S, Buback C, et al.

36 Prospective Cohort Study on Performance of Cerebrospinal Fluid (CSF) Xpert MTB/RIF, CSF

37 Lipoarabinomannan (LAM) Lateral Flow Assay (LFA), and Urine LAM LFA for Diagnosis of

38 Tuberculous Meningitis in Zambia. J Clin Microbiol. 2019;57(8). 


\section{ACKNOWLEDGEMENTS}

1 We thank Le Kim Thanh, Pham Thi Kim, Vu Thi Mong Dung and Lam Anh Nguyet for their

2 logistic support, and Dr Nguyen Thi Hoang Mai for her help with material collection. We are

3 indebted to patients for their participations in this study and the doctors and nurses of Viet Anh

4 ward, HTD, who cared for the patients.

5 This study was funded by the Wellcome Trust of Great Britain (106680/B/14/Z and

6 204904/Z/16/Z awarded to GT and LVT, respectively). 


\section{LEGENDS TO FIGURES}

1 Figure 1: An overview of protein marker discovery phases and origin of clinical samples used for the analysis

Note to Figure 1: TBM: tuberculous meningitis, cTBM: confirmed tuberculous meningitis, sTBM: clinically suspected tuberculous meningitis, BM: bacterial meningitis, cBM: confirmed bacterial meningitis, sBM: clinically suspected bacterial meningitis, EN: encephalitis, cEN: confirmed encephalitis, sEN: clinically suspected encephalitis, NI: non-CNS infections

\#Including: S. suis $(\mathrm{n}=20), S$. pneumonia $(\mathrm{n}=6)$, E. coli $(\mathrm{n}=5), N$. meningitides $(\mathrm{n}=2), B$. pseudomallei $(\mathrm{n}=1)$, E. faecalis $(\mathrm{n}=1)$, E. gallinarum $(\mathrm{n}=1), S$. agalactiae $(\mathrm{n}=1)$, . aureus $(\mathrm{n}=1)$, $S$. gallolyticus $(\mathrm{n}=1)$ and gram staining positive only $(\mathrm{n}=5)$ *including: herpes simplex virus $(n=11)$, varicella zoster virus $(n=7)$, dengue virus $(n=5)$, Japanese encephalitis virus $(n=2)$, dengue virus/Japanese encephalitis virus $(n=1)$, mumps virus $(\mathrm{n}=1)$, measles virus $(\mathrm{n}=1)$ and influenza A virus $(\mathrm{n}=1)$

\$ncluding: cryptococcal meningitis $(n=14)$, anti-NMDAR encephalitis $(n=17)$, eosinophilic

15 meningitis $(n=10)$, neurotoxoplasmosis $(n=2)$

Figure 2. Results of mass-spectrometry and LCN2 ELISA analysis of the discovery cohort. (A) Heatmap showing clinical entities clustering based on the protein/peptide profiles obtained from label-free quantitative mass-spectrometry analysis of 45 patients of the discovery phase. Columns represent clinical entities, while rows represent individual proteins, (B) Dot plots demonstrating the difference in CSF LCN2 levels between BM and non-BM groups obtained from quantitative ELISA analysis, (C) AUROC curve based on LCN2 levels measured by quantitative ELISA analysis

Note to Figure 2. Non-BM: non bacterial meningitis (encephalitis, tuberculous meningitis or

24 non-CNS infections)

Figure 3. Results of LCN2 ELISA and AUROC analysis of the validation cohort. (A) LCN2 concentrations in patients with meningitis, tuberculous meningitis, encephalitis and others (cryptococcal meningitis, anti-NMDAR encephalitis, eosinophilic meningitis, neurotoxoplasmosis and non-CNS infections), (B) AUROC curves showing the diagnostic values of LCN2 in discriminating bacterial meningitis from other CNS infections entities

Note to Figure 3: Others: patients with other CNS infections (cryptococcal meningitis, antiNMDAR encephalitis, neurotoxoplasmosis, or eosinophilic meningitis) or non-CNS infections,

32 Non-BM: non bacterial meningitis

33 Figure 4. Diagnostic values of LCN2 in predicting bacterial meningitis in comparison and

34 in combination with existing CSF parameters. (A) AUROC curves showing that LCN2 is

35 better than the existing CSF parameters in distinguishing between bacterial meningitis with other 36 CNS infections (tuberculous meningitis, encephalitis, anti-NMDAR encephalitis, cryptococcal 37 meningitis, neurotoxoplasmosis, eosinophilic meningitis or non-CNS infections), (B) AUCROC 38 values of subgroup analyses, $(\mathbf{C})$ AUROC curves showing that LCN2 significantly improves the 
1 discriminatory ability of the diagnostic model for bacterial meningitis using the remaining CNS

2 infections groups as controls, (D) AUROC values of subgroup analyses

3 Note to Figure 4: WCC: white blood cell count (leukocyte count) 

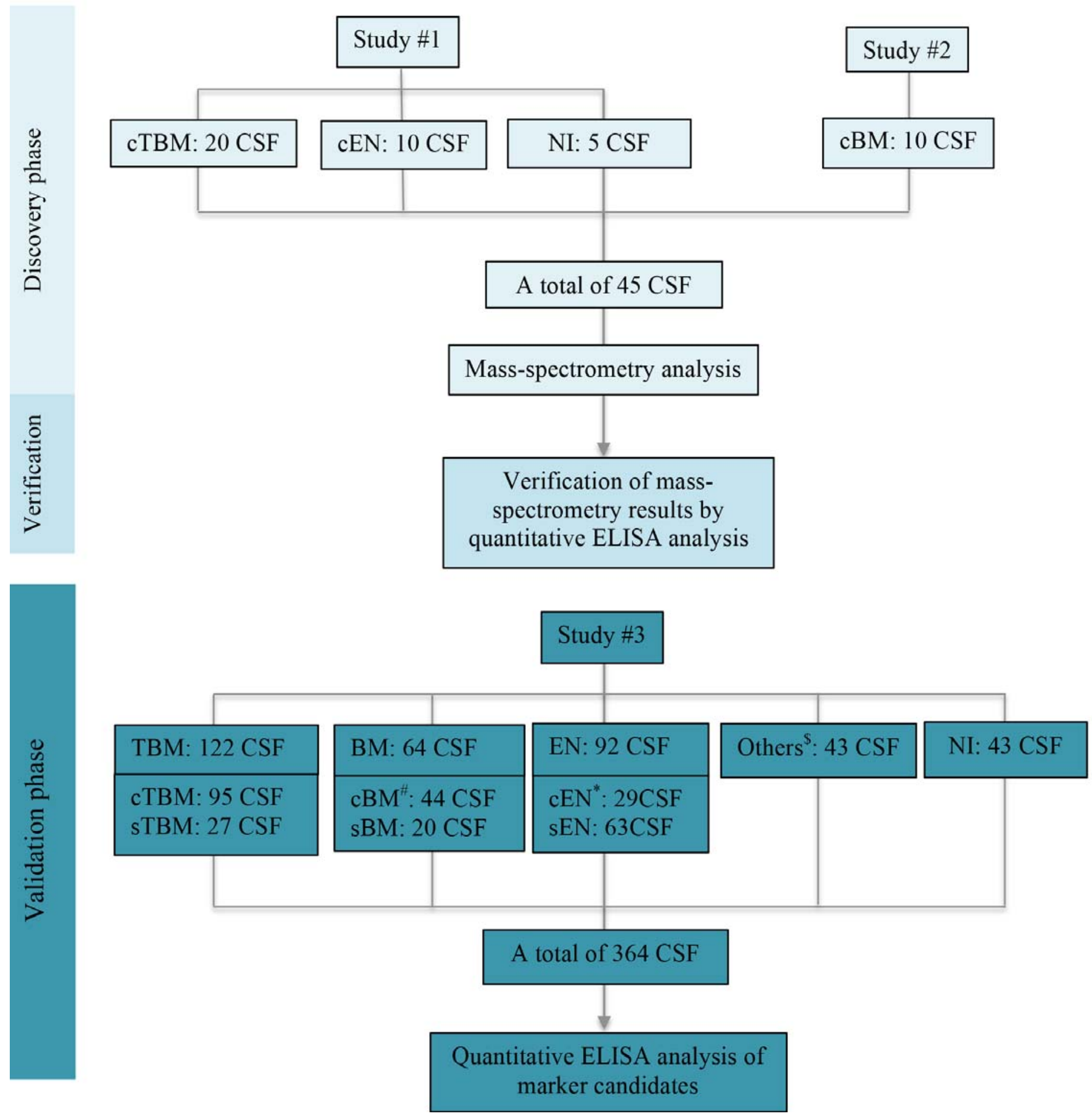

Figure 1: An overview of protein marker discovery phases and origin of clinical samples used for the analysis

Note to Figure 1: TBM: tuberculous meningitis, cTBM: confirmed tuberculous meningitis, sTBM: clinically suspected tuberculous meningitis, BM: bacterial meningitis, cBM: confirmed bacterial meningitis, sBM: clinically suspected bacterial meningitis, EN: encephalitis, cEN: confirmed encephalitis, sEN: clinically suspected encephalitis, NI: non-CNS infections

"Including: S. suis $(\mathrm{n}=20)$, S. pneumonia $(\mathrm{n}=6)$, E. coli $(\mathrm{n}=5), N$. meningitides $(\mathrm{n}=2)$, B. pseudomallei $(\mathrm{n}=1)$, E. faecalis $(\mathrm{n}=1)$, E. gallinarum $(\mathrm{n}=1)$, S. agalactiae $(\mathrm{n}=1)$, S. aureus $(\mathrm{n}=1), S$. gallolyticus $(\mathrm{n}=1)$ and gram staining positive only $(\mathrm{n}=5)$

*including: herpes simplex virus $(n=11)$, varicella zoster virus $(n=7)$, dengue virus $(n=5)$, Japanese encephalitis virus $(n=2)$, dengue virus/Japanese encephalitis virus $(n=1)$, mumps virus $(n=1)$, measles virus $(n=1)$ and influenza A virus $(n=1)$

${ }^{\$}$ Including: cryptococcal meningitis $(\mathrm{n}=14)$, anti-NMDAR encephalitis $(\mathrm{n}=17)$, eosinophilic meningitis $(\mathrm{n}=10)$, neurotoxoplasmosis $(\mathrm{n}=2)$ 
A
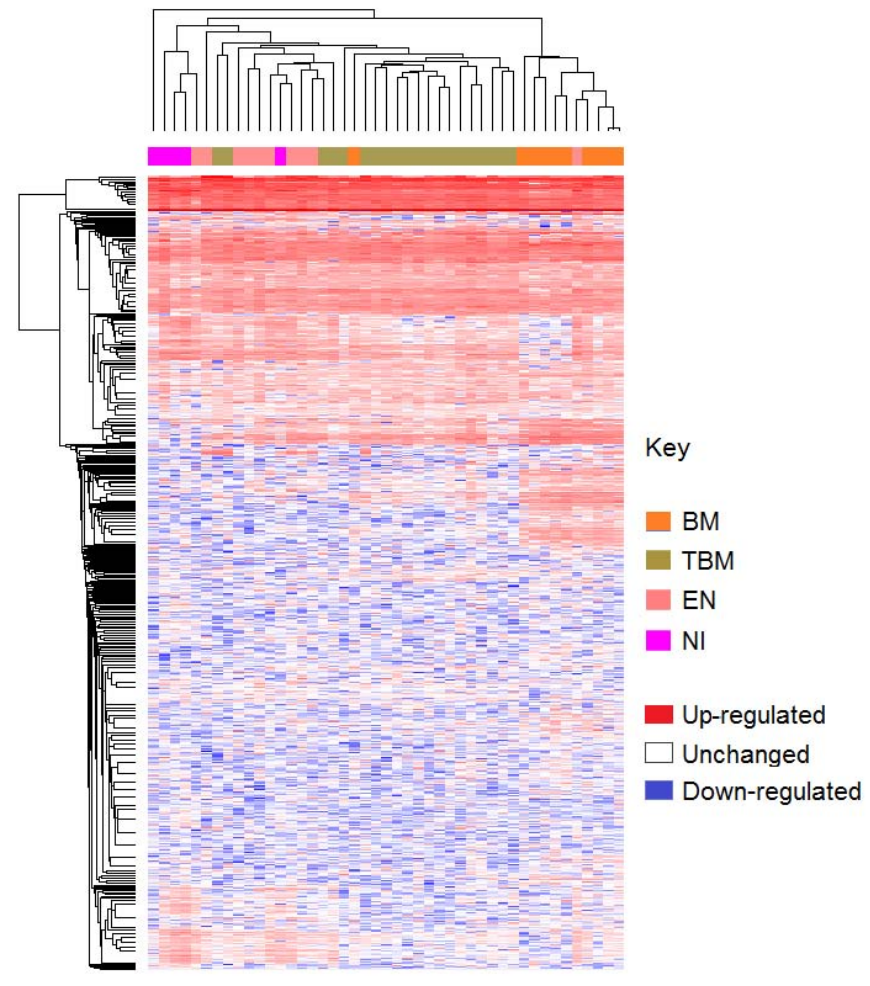

Figure 2. Results of mass-spectrometry and LCN2 ELISA analysis of the discovery cohort. (A) Heatmap showing clinical entities clustering based on the protein/peptide profiles obtained from label-free quantitative mass-spectrometry analysis of 45 patients of the discovery phase. Columns represent clinical entities, while rows represent individual proteins, (B) Dot plots demonstrating the difference in CSF LCN2 levels between BM and non-BM groups obtained from quantitative ELISA analysis, (C) AUROC curve based on LCN2 levels measured by quantitative ELISA analysis

Note to Figure 2. Non-BM: non bacterial meningitis (encephalitis, tuberculous meningitis or non-CNS infections)

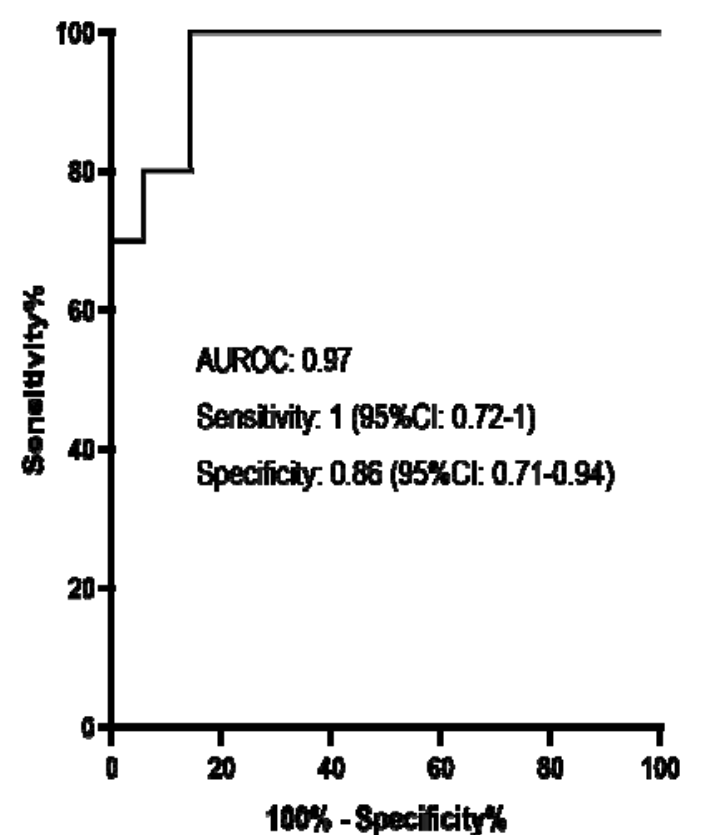


A

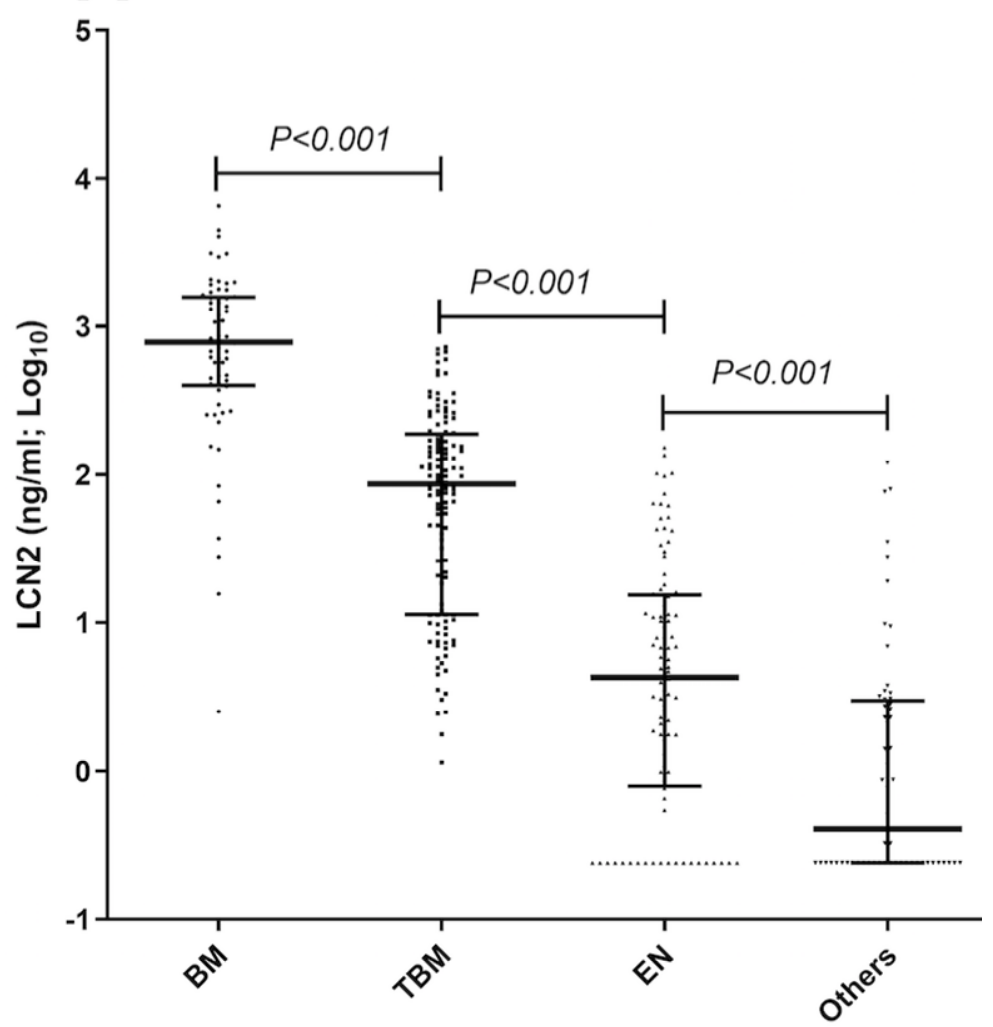

B

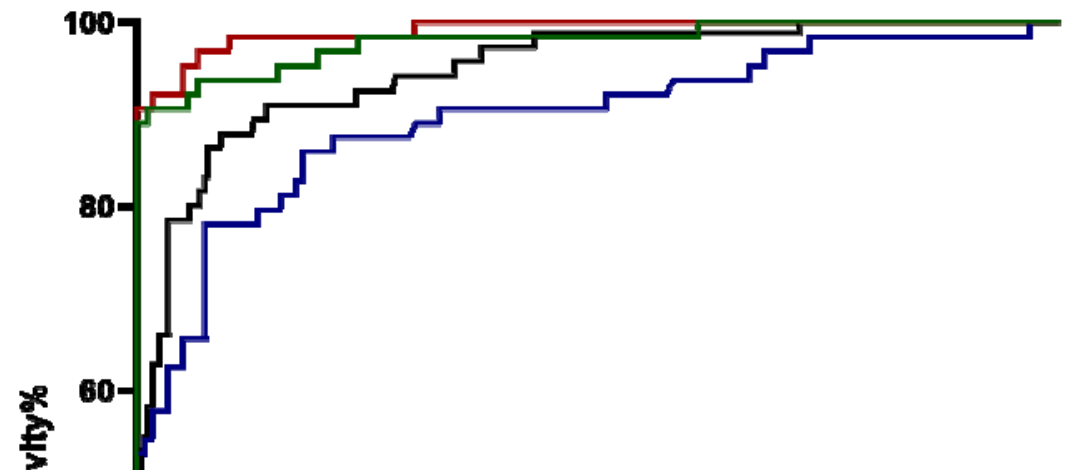

- BMvs Non-BM

- BMvs EN

- BM vs TBM

- BM vs Others

$\mathbf{2 0}$

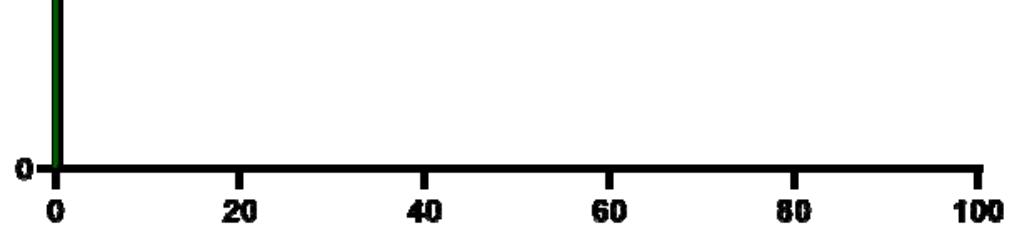

$100 \%$ - Spectilcity\%

\begin{tabular}{|l|c|c|c|c|c|}
\hline BM vs. & $\begin{array}{c}\text { LCN2 cut- } \\
\text { off (ng/ml) }\end{array}$ & AUC (95\%CI) & $\begin{array}{c}\text { Sensitivity } \\
(\mathbf{9 5 \%} \% \text { I) }\end{array}$ & $\begin{array}{c}\text { Specificity } \\
\text { (95\%CI) }\end{array}$ & DOR \\
\hline Non-BM & 221 & $0.95(0.92-0.98)$ & $0.88(0.77-0.94)$ & $0,91(0.88-0.94)$ & $73.8(31.8-171.4)$ \\
\hline TBM & 365 & $0.90(0.84-0.95)$ & $0.78(0.67-0.87)$ & $0.93(0.87-0.96)$ & $44.8(18.2-110.4)$ \\
\hline EN & 142 & $0.98(0.96-1)$ & $0.91(0.81-0.96)$ & $0.99(0.94-1)$ & $879.7(103.2-7495.1)$ \\
\hline Others & 134 & $0.99(0.98-1)$ & $0.91(0.81-0.96)$ & $1(0.94-1)$ & NA \\
\hline
\end{tabular}

Figure 3. Results of LCN2 ELISA and AUROC analysis of the validation cohort. (A) LCN2 concentrations in patients with meningitis, tuberculous meningitis, encephalitis and others (cryptococcal meningitis, anti-NMDAR encephalitis, eosinophilic meningitis, neurotoxoplasmosis and non-CNS infections), (B) AUROC curves showing the diagnostic values of LCN2 in discriminating bacterial meningitis from other CNS infections entities

Note to Figure 3: Others: patients with other CNS infections (cryptococcal meningitis, anti-NMDAR encephalitis, neurotoxoplasmosis, or eosinophilic meningitis) or non-CNS infections, Non-BM: non bacterial meningitis 
bioRxiv preprint doi: https://doi.org/10.1101/2020.01.13.899625; this version posted January 31, 2020. The copyright holder for this preprint (which was not certified by peer review) is the author/funder, who has granted bioRxiv a license to display the preprint in perpetuity, ltis made

A

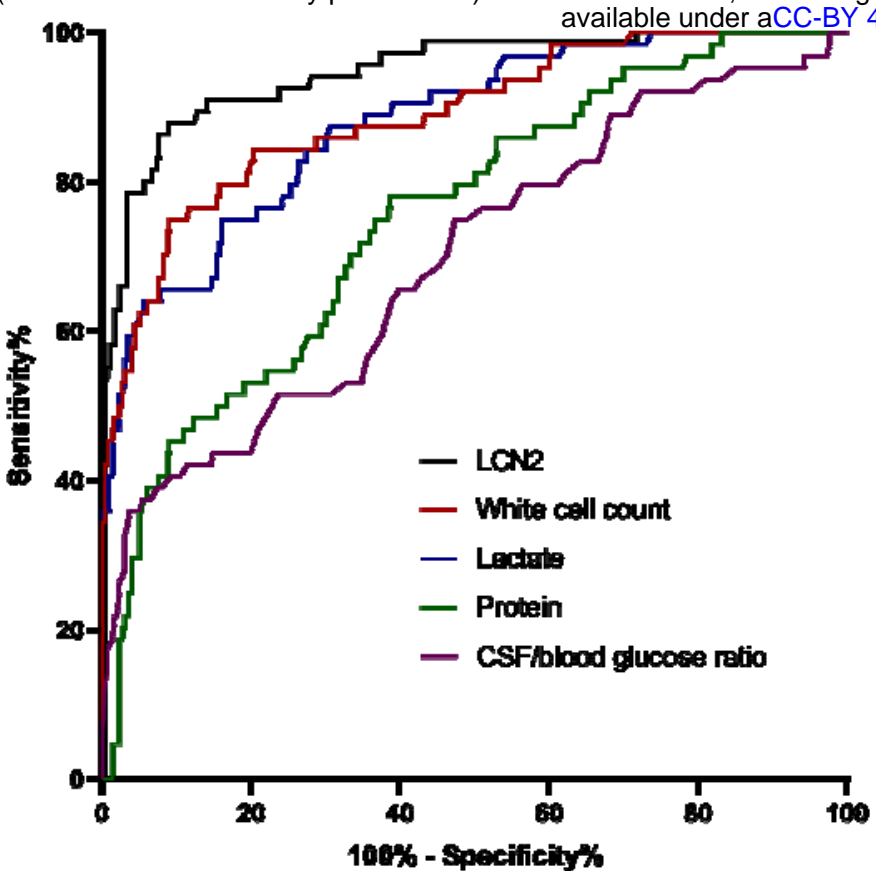

$\mathbf{C}$

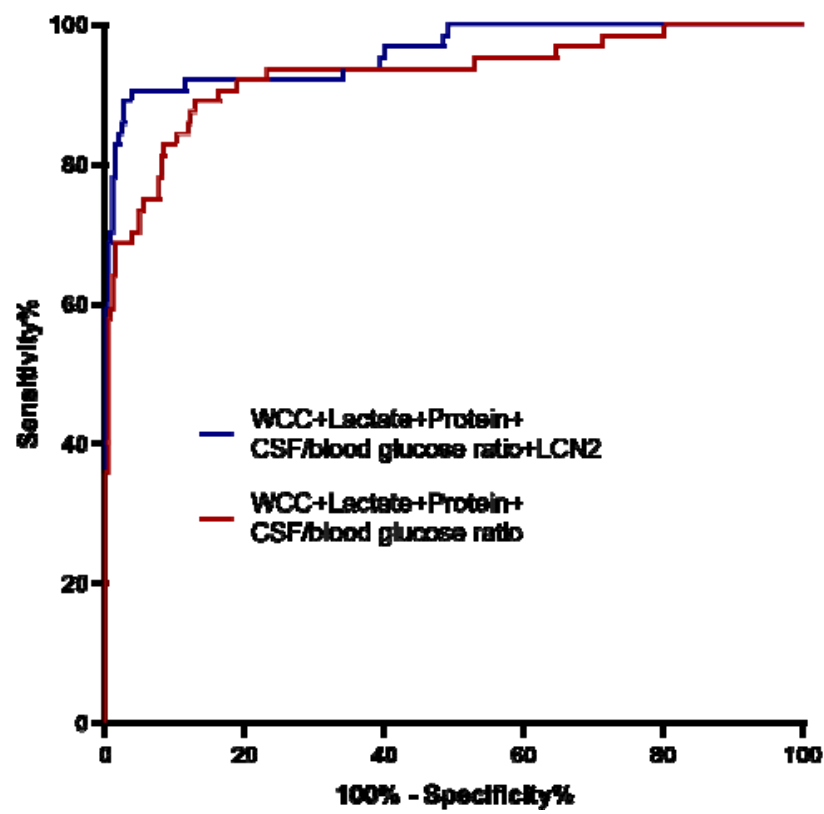

B
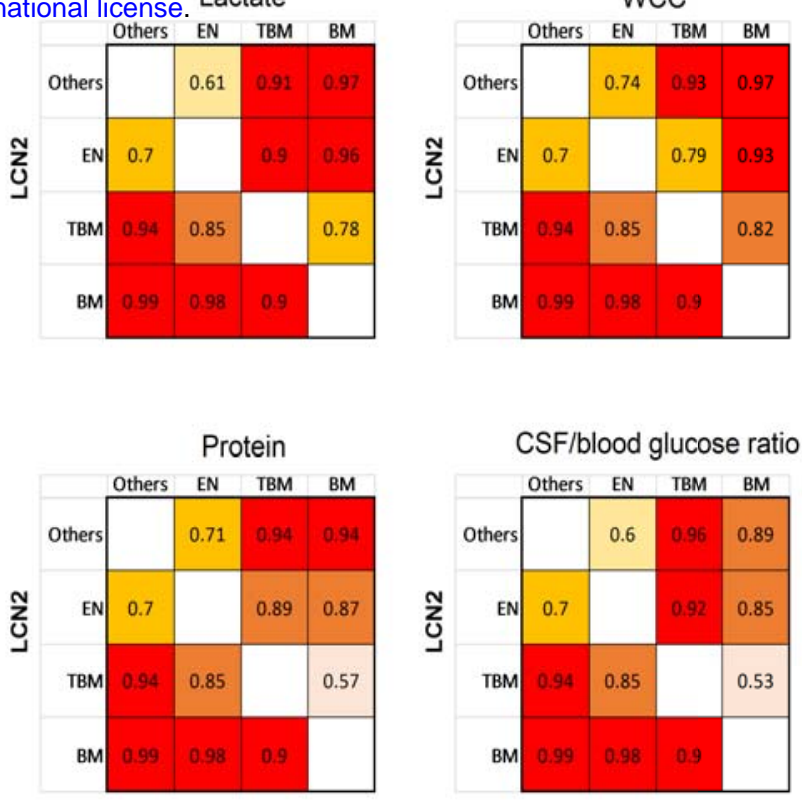

D

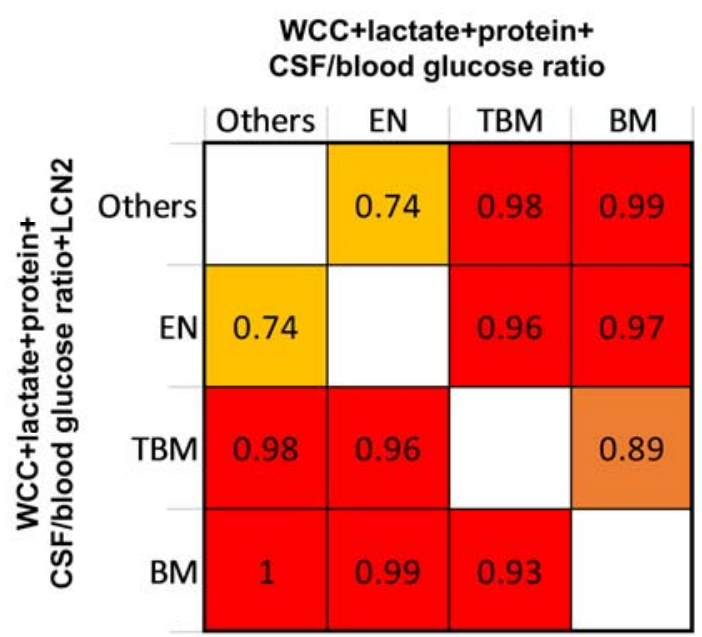

\begin{tabular}{|l|c|c|}
\hline \multicolumn{1}{|c|}{ BM vs. non-BM } & $\begin{array}{c}\text { WCC+lactate+protein+ } \\
\text { CSF/blood glucose ratio }\end{array}$ & $\begin{array}{c}\text { WCC+lactate+protein+ } \\
\text { CSF/blood glucose ratio +LCN2 }\end{array}$ \\
\hline AUC (95\%CI) & $0.94(0.90-0.98)$ & $0.96(0.93-0.99)$ \\
\hline Sensitivity $(95 \% \mathrm{CI})$ & $0.86(0.75-0.92)$ & $0.91(0.81-0.96)$ \\
\hline Specificity $(95 \% \mathrm{CI})$ & $0.92(0.88-0.94)$ & $0.97(0.94-0.98)$ \\
\hline DOR & $66.2(29.3-149.7)$ & $308.3(105.6-899.4)$ \\
\hline
\end{tabular}

Figure 4. Diagnostic values of LCN2 in predicting bacterial meningitis in comparison or in combination with existing CSF parameters. (A) AUROC curves showing that LCN2 is better than the existing CSF parameters in distinguishing between bacterial meningitis with other CNS infections (tuberculous meningitis, encephalitis, anti-NMDAR encephalitis, crytococcal meningitis, neurotoxoplasmosis, eosinophilic meningitis or non-CNS infections), (B) AUCROC values of subgroup analyses, (C) AUROC curves showing that LCN2 significantly improves the discriminatory ability of the diagnostic model for bacterial meningitis using the remaining CNS infections groups as controls, (D) AUROC values of subgroup analyses

Note to Figure 4: WCC: white blood cell count (leukocyte count) 
bioRxiv preprint doi: https://doi.org/10.1101/2020.01.13.899625; this version posted January 31, 2020. The copyright holder for this preprint (which was not certified by peer review) is the author/funder, who has granted bioRxiv a license to display the preprint in perpetuity. It is made available under aCC-BY 4.0 International license.

\section{SUPPLEMENTARY MATERIALS}


Table S1. Diagnostic tests carried out as part of routine care and/or as per the study protocols

\begin{tabular}{|l|c|c|c|}
\hline & Study \#1 & Study \#2 & Study \#3 \\
\hline Gram stain & Y & Y & Y \\
\hline Bacterial culture & Y & Y & Y \\
\hline Ziehl-Neelsen staining & Y & Y & Y \\
\hline GenXpert & Y & Y & Y \\
\hline MGIT & Y & Y & Y \\
\hline S. suis PCR & Y & Y & Y \\
\hline S. pneumoniae PCR & Y & Y & Y \\
\hline N. meningitidis PCR & Y & Y & Y \\
\hline 16S rRNA PCR & ND & Y & Y \\
\hline HSV PCR & Y & Y & Y \\
\hline VZV PCR & Y & Y & Y \\
\hline DENV PCR & ND & ND & Y \\
\hline JEV PCR & ND & ND & Y \\
\hline Flavivirus PCR & ND & ND & Y \\
\hline Enterovirus PCR & ND & ND & Y \\
\hline Influenza A virus & Y & Y & Y \\
\hline Mumps virus PCR & ND & ND & Y \\
\hline Zika virus PCR & ND & ND & Y \\
\hline Angiostrongylus cantonensis PCR & ND & ND & Y \\
\hline Cryptococcal FLA & Y & Y & Y \\
\hline DENV serology & Y & Y & Y \\
\hline JEV serology & ND & Y & Y \\
\hline Anti-NMDAR & & \\
\hline
\end{tabular}

Note to Table S1: Y: yes. ND: not done 
Table S2. Baseline characteristics of the discovery and validation cohort

\begin{tabular}{|c|c|c|c|c|c|c|c|c|c|c|c|}
\hline & \multicolumn{4}{|c|}{ Discovery cohort } & \multicolumn{7}{|c|}{ Validation cohort } \\
\hline & TBM $(\mathrm{N}=20)$ & $\begin{array}{l}\text { Encephalitis } \\
\quad(\mathrm{N}=10)\end{array}$ & $\mathrm{BM}^{2}(\mathrm{~N}=10)$ & $\begin{array}{c}\text { Non-CNS } \\
\text { infections } \\
(\mathrm{N}=5)\end{array}$ & $\mathrm{BM}(\mathrm{N}=64)^{\#}$ & $\operatorname{TBM}(\mathrm{N}=122)^{-3}$ & $\begin{array}{c}\text { Encephalitis } \\
(\mathrm{N}=92)^{\mathrm{s}}\end{array}$ & $\begin{array}{l}\text { Anti-NMDAR } \\
(\mathrm{N}=17)\end{array}$ & $\begin{array}{c}\text { Eosinophilic } \\
\text { meningitis }(\mathrm{N}=10)\end{array}$ & $\begin{array}{c}\text { Cryptococcal } \\
\text { meningitis } \\
(\mathrm{N}=14)\end{array}$ & $\begin{array}{c}\text { Non-CNS } \\
\text { infections } \\
(\mathrm{N}=43)\end{array}$ \\
\hline \multicolumn{12}{|l|}{ Demographics } \\
\hline Age in years & $40(23-75)$ & $33(18-53)$ & $49(23-74)$ & $58(0-70)$ & $55(17-87)$ & $41(17-87)$ & $31(16-78)$ & $25(17-48)$ & $30(18-60)$ & $35.5(22-68)$ & $48(20-92)$ \\
\hline Gender & $11 / 9$ & $8 / 2$ & $7 / 3$ & $2 / 3$ & $44 / 20$ & $97 / 25$ & $54 / 38$ & $9 / 8$ & $4 / 6$ & $10 / 4$ & $25 / 18$ \\
\hline Ho Chi Minh City origin & $5(25)$ & $2(20)$ & $4(44.4)$ & $2(40)$ & $12(18.8)$ & $29(23.8)$ & $27(29.3)$ & $3(17.6)$ & $2(20)$ & $4(28.6)$ & $10(23.3)$ \\
\hline Illness day at enrollment & $14(0-60)$ & $5(0-10)$ & $2(0-13)$ & $4(3-18)$ & $4(1-30)$ & $12(2-90)$ & $6(1-90)$ & $22(6-37)$ & $25.5(7-60)$ & $18(4-30)$ & $5(1-60)$ \\
\hline Length of hospital stay & $24(0-59)$ & $5(0-67)$ & 18(13-26) & $2(1-17)$ & $14(1-119)$ & $26(0-162)$ & $11(0-118)$ & $41(27-102)$ & $11(1-23)$ & $23(0-134)$ & $8(0-75)$ \\
\hline \multicolumn{12}{|l|}{ Clinical signs/symptoms } \\
\hline Fever $(\mathrm{n}, \%)$ & 19(95) & $10(100)$ & NA & $5(100)$ & 59(96.7) & $117(96.7)$ & $83(92.2)$ & $13(76.5)$ & $7(70)$ & $12(85.7)$ & $36(87.8)$ \\
\hline Headache $(\mathrm{n}, \%)$ & $18(90)$ & $10(100)$ & $6(66.7)$ & $3(60)$ & $57(91.9)$ & $113(96.6)$ & $64(76.2)$ & $9(64.3)$ & $10(100)$ & $13(92.9)$ & $15(40.5)$ \\
\hline Cranial nerve palsy $(\mathrm{n}, \%)$ & $4(20)$ & $2(20)$ & NA & 0 & $5(7.8)$ & $23(18.9)$ & $9(9.8)$ & 0 & $3(30)$ & $4(28.6)$ & $3(7)$ \\
\hline Hemiplegia $(\mathrm{n}, \%)$ & $1(5)$ & $2(20)$ & NA & 0 & $1(1.6)$ & $12(9.8)$ & $4(4.3)$ & 0 & $1(10)$ & $1(7.1)$ & $3(7)$ \\
\hline Paraplegia $(\mathrm{n}, \%)$ & 0 & 0 & NA & 0 & $1(1.6)$ & $10(8.2)$ & $3(3.3)$ & 0 & $1(10)$ & $1(7.1)$ & $4(9.3)$ \\
\hline Tetraplegia $(\mathrm{n}, \%)$ & 0 & 0 & NA & 0 & $1(1.6)$ & $5(4.1)$ & $3(3.3)$ & 0 & 0 & $1(7.1)$ & $4(9.3)$ \\
\hline Convulsions $(\mathrm{n}, \%)$ & $1(5)$ & $1(10)$ & NA & 0 & $1(1.6)$ & $2(1.7)$ & $15(16.5)$ & 0 & 0 & 0 & $5(11.9)$ \\
\hline Neck stiffness $(\mathrm{n}, \%)$ & $17(85)$ & $9(90)$ & NA & $4(80)$ & $47(77)$ & $57(47.6)$ & $30(33.7)$ & $5(29.4)$ & $5(50)$ & $7(50)$ & $8(19.5)$ \\
\hline GCS** at enrolment (median, range) & $14(8-15)$ & $11(7-15)$ & NA & $14(10-15)$ & $12(3-15)$ & $14(4-15)$ & $11(3-15)$ & $11(6-14)$ & $15(9-15)$ & $13(8-15)$ & $13(7-15)$ \\
\hline HIV positive, (n\%) & $2(20)$ & $1(10)$ & $\mathrm{NA}$ & 0 & 0 & $22(24.2)$ & 0 & 0 & & & $1(2.3)$ \\
\hline \multicolumn{12}{|l|}{ CSF examinations } \\
\hline CSF leukocyte count (per mm3) & $317(58-896)$ & $209(18-1571)$ & $\begin{array}{c}11000(500- \\
19200)\end{array}$ & $5(1-93)$ & $1924(24-51810)$ & $312(3-3969)$ & 43(1-909) & $23(6-187)$ & 501(140-1101) & $36.5(2-357)$ & $2(1-2700)$ \\
\hline CSF neutrophils (\%) & $26(3-93)$ & $3(0-18)$ & $91.5(83-98)$ & $20(0-87)$ & $83(10-98)$ & $26(0-95)$ & $14(0-91)$ & $14(9-65)$ & $12(7-42)$ & $26.5(0-67)$ & $30(0-93)$ \\
\hline CSF lymphocytes (\%) & $74(7-94)$ & $96(0-98)$ & $6(0.9-17)$ & $13(0-99)$ & $17(2-90)$ & $73(5-92)$ & $84(0-94)$ & $86(35-91)$ & $47(20-70)$ & $67.5(33-86)$ & $50(0-99)$ \\
\hline $\mathrm{CSF} /$ blood glucose ratio & $\begin{array}{c}0.19 \\
(0.04-0.4)\end{array}$ & $\begin{array}{c}0.61 \\
(0.5-7.66)\end{array}$ & NA & $\begin{array}{c}0.65 \\
(0.41-0.67)\end{array}$ & $0.3(0-1)$ & $0.3(0.1-0.7)$ & $4(1.7-7.7)$ & $0.8(0.5-1.4)$ & $0.4(0.4-0.9)$ & $0.3(0-0.6)$ & $0.7(0.4-1.3)$ \\
\hline CSF lactate $(\mathrm{mmol} / \mathrm{L})$ & $\begin{array}{c}6.77 \\
(3.21-12.43)\end{array}$ & $\begin{array}{c}2.79 \\
(1.88-3.52)\end{array}$ & NA & $\begin{array}{c}3.65 \\
(1.78-7.3)\end{array}$ & $9.9(2.3-28.2)$ & $5(1.9-12.8)$ & $2.5(1.3-6.6)$ & $1.9(1.4-2.7)$ & $2.7(2.2-4.2)$ & $4.9(2.7-12.7)$ & $2.5(1.4-6.4)$ \\
\hline Total protein $(\mathrm{g} / \mathrm{L})$ & $2(1.1-4.1)$ & $0.8(0.3-2.4)$ & NA & $0.5(0.3-2.6)$ & $2.3(0.3-8.7)$ & $1.9(0.2-29.8)$ & $0.7(0.1-3.2$ & $0.3(0.2-0.8)$ & $0.8(0.2-3.9)$ & $0.6(0.4-1.8)$ & $0.4(0.2-3.2)$ \\
\hline \multicolumn{12}{|l|}{ Discharge $\mathrm{mRS}^{\wedge}$} \\
\hline thos & $3(15)$ & 0 & NA & $1(20)$ & $8(12.5)$ & $22(18)$ & $17(18.2)$ & 0 & 0 & 0 & 5(11.6) \\
\hline 1 & $3(15)$ & $2(20)$ & NA & 0 & $6(9.4)$ & $16(13.1)$ & 19(20.7) & $2(11.8)$ & $3(30)$ & 0 & $6(14)$ \\
\hline 2 & $5(25)$ & 0 & NA & $2(40)$ & $12(18.8)$ & $15(13.2)$ & 19(20.7) & 0 & $4(40)$ & $1(7.1)$ & $8(18.6)$ \\
\hline 3 & $4(20)$ & $4(40)$ & NA & $1(20)$ & $20(31.3)$ & $14(11.5)$ & $12(13)$ & $6(35.3)$ & $1(10)$ & $4(28.6)$ & $8(18.6)$ \\
\hline 4 & $1(5)$ & $2(20)$ & NA & 0 & $11(17.2)$ & $22(18)$ & $13(14.1)$ & $3(17.6)$ & $1(10)$ & $3(21.4)$ & $9(20.9)$ \\
\hline 5 & $2(10)$ & $2(20)$ & NA & 0 & $3(4.7)$ & $17(13.7)$ & $10(10.9)$ & $5(29.4)$ & $1(10)$ & $1(7.1)$ & $6(14)$ \\
\hline 6 & $2(10)$ & 0 & NA & $1(20)$ & $4(6.3)$ & $16(13.1)$ & $2(2.2)$ & $1(5.9)$ & 0 & $5(35.7)$ & $1(2.3)$ \\
\hline
\end{tabular}

Note to Table S2: ' outcomes at discharge were recorded as full recovery $(n=4)$ or neurological deficit $(n=4) *$ due to the small sample size, data on two cases with

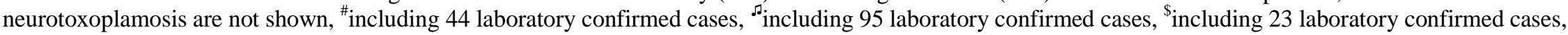
**Glasgow coma score, ${ }^{\wedge}$ Modified Rankin Scale (0: full recovery with no symptoms, 1: No significant disability, 2: Slight disability, 3: Moderate disability, 4: Moderately severe disability, 5: Severe disability, and 6: Dead); BM: bacterial meningitis, TBM: tuberculous meningitis; Data are number (\%), continuous variables are presented as median (range) 
bioRxiv preprint doi: https://doi.org/10.1101/2020.01.13.899625; this version posted January 31, 2020. The copyright holder for this preprint (which was not certified by peer review) is the author/funder, who has granted bioRxiv a license to display the preprint in perpetuity. It is made available under aCC-BY 4.0 International license.

Table S3. List of marker candidates identified by mass spectrometry analysis

\begin{tabular}{|c|c|c|c|c|c|c|c|}
\hline \multicolumn{8}{|c|}{ BM group } \\
\hline No & Protein ID & Protein name & Gene name & $\begin{array}{c}\text { Mean } \\
\text { intensity } \\
\text { of } B M \\
\left(\log _{2}\right)\end{array}$ & $\begin{array}{c}\text { Mean } \\
\text { intensity } \\
\text { of Other } \\
\left(\log _{2}\right)\end{array}$ & $\begin{array}{c}\text { Difference } \\
\text { in intensity } \\
\text { between } \\
\text { BM and } \\
\text { Others }\end{array}$ & $\begin{array}{l}-\log (p \\
\text { value })\end{array}$ \\
\hline 1 & P06744 & Glucose-6-phosphate isomerase & GPI & -19.99 & -24.54 & -4.55 & 7.74 \\
\hline 2 & P60660-2 & Myosin light polypeptide 6 & MYL6 & -19.77 & -26.05 & -6.28 & 7.3 \\
\hline 3 & P28676 & Grancalcin & GCA & -21.18 & -26.58 & -5.4 & 7.11 \\
\hline 4 & P11413-2 & Glucose-6-phosphate 1-dehydrogenase & G6PD & -21.17 & -26.4 & -5.23 & 6.31 \\
\hline 5 & P26583 & High mobility group protein $\mathrm{B} 2$ & HMGB2 & -20.83 & -26.23 & -5.41 & 5.3 \\
\hline 6 & P05109 & Protein S100-A8 & S100A8 & -14.87 & -20.83 & -5.96 & 5.87 \\
\hline 7 & P05164-2 & Myeloperoxidase & MPO & -18.03 & -23.71 & -5.68 & 5.84 \\
\hline 8 & P06702 & Protein S100-A9 & S100A9 & -14.55 & -21.29 & -6.75 & 5.84 \\
\hline 9 & P43490 & Nicotinamide phosphoribosyltransferase & NAMPT & -21.54 & -26.07 & -4.53 & 5.82 \\
\hline 10 & P80188-2 & Neutrophil gelatinase-associated lipocalin & LCN2 & -17.82 & -23.6 & -5.78 & 5.81 \\
\hline 11 & P22894 & Neutrophil collagenase & MMP8 & -19.34 & -24.07 & -4.75 & 5.77 \\
\hline 12 & P50395 & Rab GDP dissociation inhibitor beta & GDI2 & -20.2 & -24.66 & -4.46 & 5.74 \\
\hline 13 & P20160 & Azurocidin & AZU1 & -20.45 & -26.12 & -5.67 & 5.61 \\
\hline 14 & P41218 & Myeloid cell nuclear differentiation antigen & MNDA & -19.89 & -24.52 & -4.63 & 5.60 \\
\hline 15 & P61160 & Actin-related protein 2 & ACTR2 & -21.19 & -25.46 & -4.27 & 5.47 \\
\hline 16 & O15144 & Actin-related protein $2 / 3$ complex subunit 2 & ARPC2 & -19.86 & -25.15 & -5.29 & 5.47 \\
\hline 17 & P08670 & Vimentin & VIM & -18.54 & -22.2 & -3.66 & 5.46 \\
\hline 18 & P08107 & Heat shock $70 \mathrm{kDa}$ protein $1 \mathrm{~A}$ & HSPA1A & -19.45 & -24.1 & -4.65 & 5.37 \\
\hline 19 & P30044-2 & Peroxiredoxin-5, mitochondrial & PRDX5 & -20.84 & -25.66 & -4.82 & 5.23 \\
\hline 20 & P04040 & Catalase & CAT & -19.23 & -24.71 & -5.48 & 5.22 \\
\hline 21 & P09429 & High mobility group protein B1 & HMGB1 & -21.35 & -25.89 & -4.53 & 5.12 \\
\hline 22 & P61158 & Actin-related protein 3 & ACTR3 & -20.73 & -25.39 & -4.66 & 5.03 \\
\hline 23 & P35579 & Myosin-9 & MYH9 & -21.18 & -26.72 & -5.54 & 5.02 \\
\hline 24 & P04083 & Annexin A1 & ANXA1 & -19.86 & -25.38 & -5.52 & 4.81 \\
\hline 25 & P49913 & Cathelicidin antimicrobial peptide & CAMP & -20.72 & -24.6 & -3.88 & 4.74 \\
\hline 26 & P12814-3 & Alpha-actinin-1 & ACTN1 & -20.87 & -25.06 & -4.18 & 4.73 \\
\hline 27 & U3KPS2 & Myeloblastin & PRTN3 & -19.02 & -22.98 & -3.96 & 4.71 \\
\hline 28 & P01040 & Cystatin-A & CSTA & -18.79 & -24.16 & -5.37 & 4.7 \\
\hline 29 & Q6UX06 & Olfactomedin-4 & OLFM4 & -22.21 & -26.55 & -4.33 & 4.69 \\
\hline 30 & P52209-2 & 6-phosphogluconate dehydrogenase, decarboxylating & PGD & -19.4 & -24.03 & -4.63 & 4.67 \\
\hline 31 & P37837 & Transaldolase & TALDO1 & -19.90 & -24.88 & -4.98 & 4.6 \\
\hline 32 & P51149 & Ras-related protein Rab-7a & RAB7A & -21.76 & -25.96 & -4.21 & 4.59 \\
\hline 33 & P08246 & Neutrophil elastase & ELANE & -17.89 & -23.13 & -5.24 & 4.59 \\
\hline 34 & O15143 & Actin-related protein $2 / 3$ complex subunit $1 \mathrm{~B}$ & ARPC1B & -21.64 & -26.41 & -4.77 & 4.58 \\
\hline 35 & O43707 & Alpha-actinin-4 & ACTN4 & -21.84 & -25.85 & -4.01 & 4.52 \\
\hline 36 & P08311 & Cathepsin G & CTSG & -19.38 & -24.24 & -4.86 & 4.48 \\
\hline 37 & P59998-3 & Actin-related protein $2 / 3$ complex subunit 4 & ARPC4 & -19.92 & -24.16 & -4.24 & 4.39 \\
\hline 38 & P61626 & Lysozyme C & LYZ & -16.34 & -18.05 & -1.71 & 4.39 \\
\hline 39 & P30041 & Peroxiredoxin-6 & PRDX6 & -21.56 & -25.35 & -3.79 & 4.35 \\
\hline 40 & P00338-3 & L-lactate dehydrogenase A chain & LDHA & -20.19 & -23.1 & -2.91 & 4.24 \\
\hline 41 & Q05315 & Galectin-10 & CLC & -21.36 & -25.34 & -3.98 & 4.18 \\
\hline 42 & P09960 & Leukotriene A-4 hydrolase & LTA4H & -21.47 & -24.95 & -3.48 & 4.15 \\
\hline 43 & O14950 & Myosin regulatory light chain 12B & MYL12B & -21.26 & -25.66 & -4.4 & 4.12 \\
\hline 44 & P09211 & Glutathione S-transferase P & GSTP1 & -18.82 & -23.38 & -4.56 & 4.1 \\
\hline 45 & P00491 & Purine nucleoside phosphorylase & PNP & -21.14 & -25.57 & -4.43 & 4.07 \\
\hline
\end{tabular}


bioRxiv preprint doi: https://doi.org/10.1101/2020.01.13.899625; this version posted January 31, 2020. The copyright holder for this preprint (which was not certified by peer review) is the author/funder, who has granted bioRxiv a license to display the preprint in perpetuity. It is made available under aCC-BY 4.0 International license.

\begin{tabular}{|c|c|c|c|c|c|c|c|}
\hline 46 & P18428 & Lipopolysaccharide-binding protein & LBP & -20.82 & -24.91 & -4.09 & 4.05 \\
\hline 47 & P60709 & Actin, cytoplasmic 1 & АСТВ & -16.18 & -17.82 & -1.65 & 4.02 \\
\hline 48 & P21333-2 & Filamin-A & FLNA & -21.85 & -26.23 & -4.38 & 4.01 \\
\hline 49 & Q9ULZ3-2 & Apoptosis-associated speck-like protein containing a CARD & PYCARD & -20.63 & -24.76 & -4.13 & 3.88 \\
\hline 50 & P47756-2 & F-actin-capping protein subunit beta & CAPZB & -21.9 & -26.33 & -4.44 & 3.85 \\
\hline 51 & P62491-2 & Ras-related protein Rab-11A & RAB11A & -21.91 & -26.14 & -4.23 & 3.82 \\
\hline 52 & Q01518 & Adenylyl cyclase-associated protein 1 & CAP1 & -20.93 & -25.4 & -4.47 & 3.77 \\
\hline 53 & O15145 & Actin-related protein $2 / 3$ complex subunit 3 & ARPC3 & -21.08 & -24.75 & -3.67 & 3.77 \\
\hline 54 & O00299 & Chloride intracellular channel protein 1 & CLIC1 & -21.69 & -26.07 & -4.38 & 3.75 \\
\hline 55 & P35754 & Glutaredoxin-1 & GLRX & -20.49 & -24.84 & -4.36 & 3.62 \\
\hline 56 & E9PR52 & Chitinase-3-like protein 2 & CHI3L2 & -21.29 & -25.72 & -4.43 & 3.6 \\
\hline 57 & P02788-2 & Lactotransferrin & LTF & -18.8 & -24.04 & -5.24 & 3.38 \\
\hline 58 & P18206-2 & Vinculin & VCL & -22.71 & -26.28 & -3.58 & 3.34 \\
\hline 59 & P52566 & Rho GDP-dissociation inhibitor 2 & ARHGDIB & -18.87 & -22.34 & -3.47 & 3.31 \\
\hline 60 & P62942 & Peptidyl-prolyl cis-trans isomerase FKBP1A & FKBP1A & -19.83 & -24.1 & -4.27 & 3.27 \\
\hline \multicolumn{8}{|c|}{ TBM group } \\
\hline No & Protein ID & Protein name & Gene name & $\begin{array}{l}\text { Mean } \\
\text { intensity } \\
\text { of } \mathbf{B M} \\
\left(\log _{2}\right)\end{array}$ & $\begin{array}{l}\text { Mean } \\
\text { intensity } \\
\text { of Other } \\
\left(\log _{2}\right)\end{array}$ & $\begin{array}{l}\text { Difference } \\
\text { in intensity } \\
\text { between } \\
\text { TBM and } \\
\text { Others }\end{array}$ & $\begin{array}{l}-\log \quad(p \\
\text { value })\end{array}$ \\
\hline 1 & P25311 & Zinc-alpha-2-glycoprotein & AZGP1 & -16.21 & -17.29 & -1.08 & 9.22 \\
\hline 2 & $\mathrm{P} 23381$ & Tryptophan-tRNA ligase & WARS & -20.06 & -23.81 & -3.75 & 5.58 \\
\hline 3 & P29622 & Kallistatin & SERPINA4 & -20.65 & -22.77 & -2.13 & 4.39 \\
\hline 4 & P02746 & Complement $\mathrm{C} 1 \mathrm{q}$ subcomponent subunit B & $\mathrm{C} 1 \mathrm{QB}$ & -18.32 & -19.31 & -0.99 & 4.35 \\
\hline 5 & A0A075B6J0 & Immunoglobulin lambda variable $1-40$ & IGLV1-40 & -17.36 & -20.25 & -2.9 & 4.25 \\
\hline 6 & P02749 & Beta-2-glycoprotein 1 & $\mathrm{APOH}$ & -18.32 & -19.33 & -1.01 & 4.13 \\
\hline 7 & P32455 & Guanylate-binding protein 1 & GBP1 & -23.23 & -25.44 & -2.21 & 3.41 \\
\hline 8 & P16070-10 & CD44 antigen & CD44 & -22.26 & -23.46 & -1.19 & 3.23 \\
\hline 9 & P02747 & Complement $\mathrm{C} 1 \mathrm{q}$ subcomponent subunit $\mathrm{C}$ & $\mathrm{C} 1 \mathrm{QC}$ & -17.8 & -18.93 & -1.13 & 3.14 \\
\hline 10 & P01591 & Immunoglobulin J chain & JCHAIN & -19.12 & -22.1 & -2.98 & 2.93 \\
\hline 11 & Q8WVN6 & Secreted and transmembrane protein 1 & SECTM1 & -20.96 & -23.77 & -2.81 & 2.88 \\
\hline 12 & Q96IY4 & Carboxypeptidase B2 & CPB2 & -21.79 & -24.05 & -2.26 & 2.83 \\
\hline 13 & Q14624 & Inter-alpha-trypsin inhibitor heavy chain $\mathrm{H} 4$ & ITIH4 & -22.42 & -24.14 & -1.72 & 2.82 \\
\hline 14 & $\mathrm{P} 01625$ & Immunoglobulin kappa variable 4-1 & IGKV4-1 & -23.58 & -26.87 & -3.29 & 2.78 \\
\hline 15 & O15204 & ADAM DEC1 & ADAMDEC1 & -22.75 & -25.26 & -2.51 & 2.64 \\
\hline 16 & P19971-2 & Thymidine phosphorylase & TYMP & -22.78 & -25.01 & -2.24 & 2.57 \\
\hline 17 & A0A075B6J9 & Immunoglobulin lambda variable 2-18 & IGLV2-18 & -21.35 & -24.22 & -2.87 & 2.37 \\
\hline 18 & P01596 & Immunoglobulin kappa variable 1-5 & IGKV1-5 & -21.02 & -23.7 & -2.69 & 2.36 \\
\hline 19 & P02743 & Serum amyloid P-component & APCS & -23.62 & -25.81 & -2.19 & 2.3 \\
\hline
\end{tabular}


Table S4. Results of analysis comparing the diagnostic value of LCN2 in distinguishing between patients with confirmed and clinically suspected bacterial meningitis

\begin{tabular}{|l|c|c|c|c|c|}
\hline cBM vs. sBM & Cut-off & $\begin{array}{c}\text { AUC } \\
(\mathbf{9 5 \%} \text { CI) }\end{array}$ & $\begin{array}{c}\text { Sensitivity } \\
\mathbf{( 9 5 \%} \text { CI) }\end{array}$ & $\begin{array}{c}\text { Specificity } \\
\mathbf{( 9 5 \%} \text { CI) }\end{array}$ & $\begin{array}{c}\text { DOR } \\
\mathbf{( 9 5 \%} \text { CI) }\end{array}$ \\
\hline LCN2 (ng/ml) & 452.3 & $\begin{array}{c}0.74 \\
(0.6-0.88)\end{array}$ & $\begin{array}{c}0.82 \\
(0.68-0.9)\end{array}$ & $\begin{array}{c}0.6 \\
(0.39-0.78)\end{array}$ & $\begin{array}{c}6.8 \\
(2.1-21.9)\end{array}$ \\
\hline CSF leukocytes (cell per mm $\left.{ }^{3}\right)$ & 1533 & $\begin{array}{c}0.61 \\
(0.47-0.76)\end{array}$ & $\begin{array}{c}0.61 \\
(0.47-0.74)\end{array}$ & $\begin{array}{c}0.65 \\
(0.43-0.82)\end{array}$ & $\begin{array}{c}3.0 \\
(1-8.9)\end{array}$ \\
\hline CSF lactate (mmol/L) & 9.0 & $\begin{array}{c}0.84 \\
(0.74-0.95)\end{array}$ & $\begin{array}{c}0.77 \\
(0.63-0.87)\end{array}$ & $\begin{array}{c}0.8 \\
(0.58-0.92)\end{array}$ & $\begin{array}{c}13.6 \\
(3.7-50.1)\end{array}$ \\
\hline CSF/blood glucose ratio & 0.2 & $\begin{array}{c}0.76 \\
(0.63-0.88)\end{array}$ & $\begin{array}{c}0.57 \\
(0.42-0.7)\end{array}$ & $\begin{array}{c}0.95 \\
(0.76-0.99)\end{array}$ & $\begin{array}{c}25 \\
(3.1-203.6)\end{array}$ \\
\hline CSF protein (g/L) & 2.1 & $\begin{array}{c}0.74 \\
(0.61-0.86)\end{array}$ & $\begin{array}{c}0.66 \\
(0.51-0.78)\end{array}$ & $\begin{array}{c}0.75 \\
(0.53-0.89)\end{array}$ & $\begin{array}{c}5.8 \\
(1.8-19)\end{array}$ \\
\hline $\begin{array}{l}\text { CSF White cell count+lactate+CSF/blood } \\
\text { glucose level+CSF protein }\end{array}$ & NA & $\begin{array}{c}0.87 \\
(0.77-0.97)\end{array}$ & $\begin{array}{c}0.95 \\
(0.85-0.99)\end{array}$ & $\begin{array}{c}0.65 \\
(0.43-0.82)\end{array}$ & $\begin{array}{c}39 \\
(7.2-21.4)\end{array}$ \\
\hline $\begin{array}{l}\text { CSF White cell count+lactate+CSF/blood } \\
\text { glucose level+CSF protein+lipocalin 2 }\end{array}$ & NA & $\begin{array}{c}0.87 \\
(0.77-0.96)\end{array}$ & $\begin{array}{c}0.95 \\
(0.85-0.99)\end{array}$ & $\begin{array}{c}0.65 \\
(0.43-0.82)\end{array}$ & $\begin{array}{c}39 \\
(7.2-21.4)\end{array}$ \\
\hline
\end{tabular}




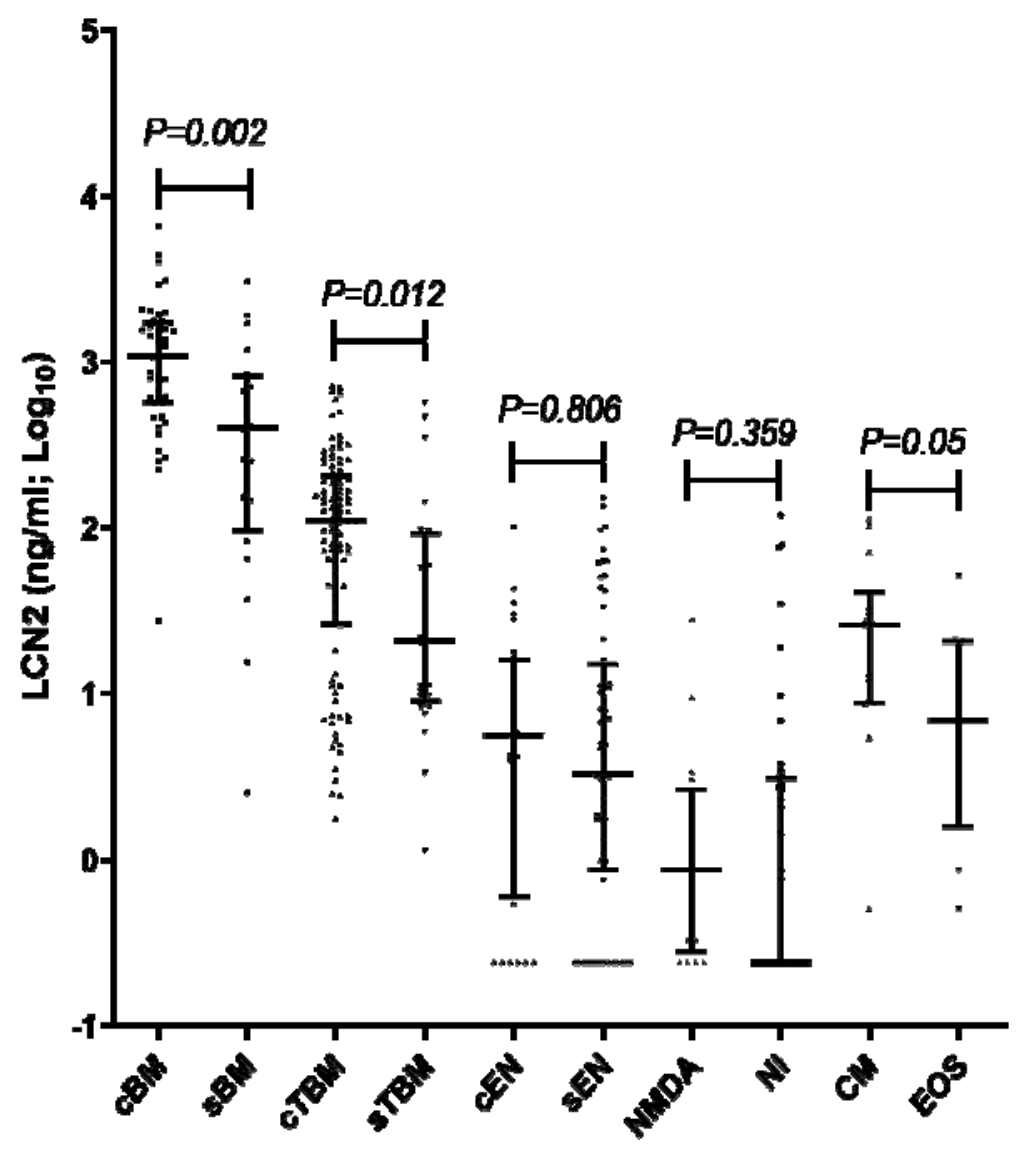

Figure S1. Plots showing the distribution of LCN2 concentrations in patients with laboratory confirmed or clinically suspected CNS infections and non-CNS infections

Note to Figure S1: cBM: confirmed bacterial meningitis, sBM: clinically suspected bacterial meningitis, cTBM: confirmed tuberculous meningitis, sTBM: clinically suspected tuberculous meningitis, cEN: confirmed encephalitis, sEN: clinically suspected encephalitis, NMDA: antiNDMAR encephalitis, NI: non-CNS infections, CM: crytococcal meningitis, EOS: eosinophilic meningitis 


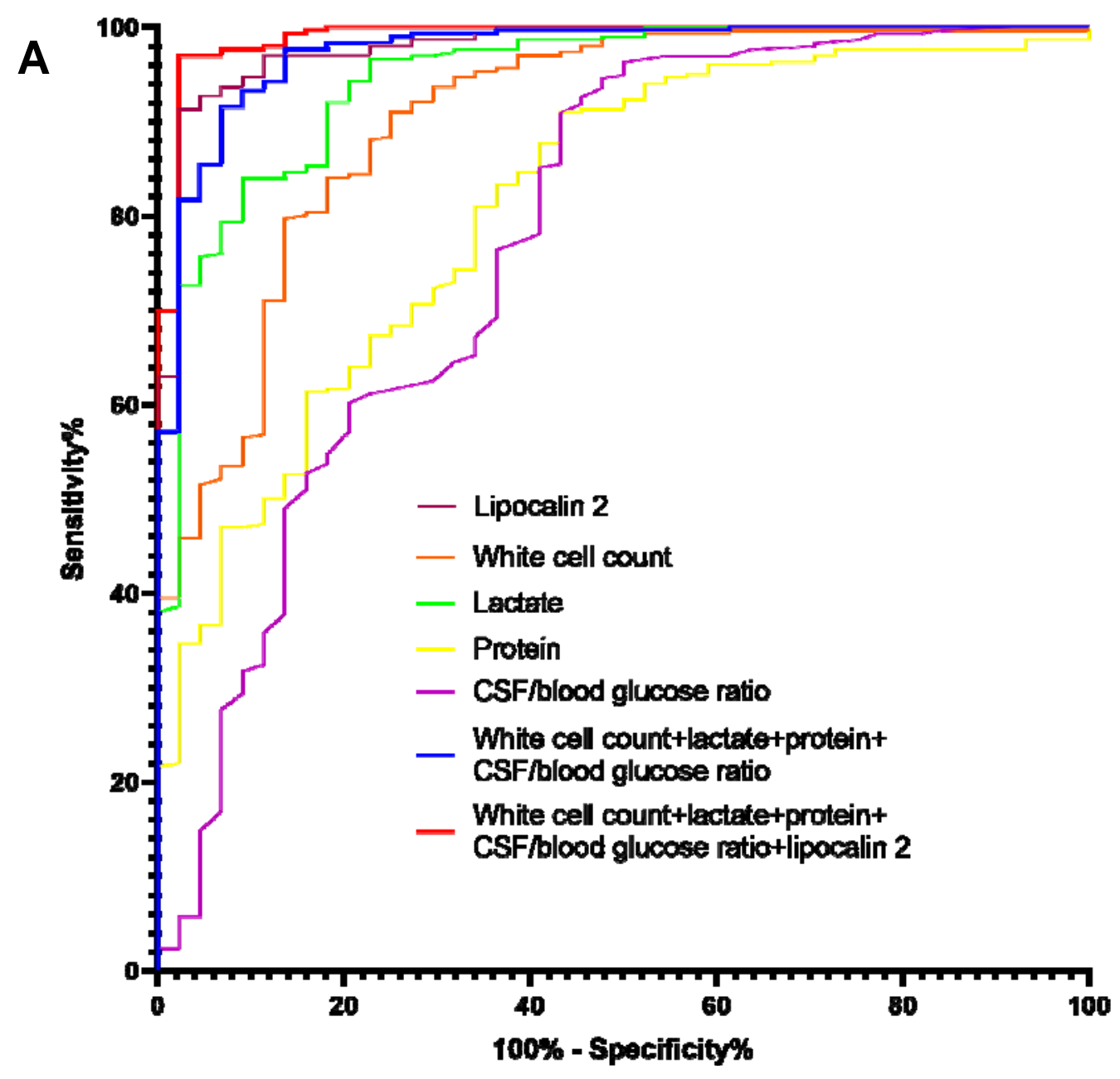

\begin{tabular}{|l|c|c|c|c|c|}
\hline cBM prediction & $\begin{array}{c}\text { Cut-off } \\
\text { values }\end{array}$ & $\begin{array}{c}\text { AUC } \\
\mathbf{( 9 5 \%} \text { CI) }\end{array}$ & $\begin{array}{c}\text { Sensitivity } \\
\mathbf{( 9 5 \%} \text { CI })\end{array}$ & $\begin{array}{c}\text { Specificity } \\
(\mathbf{9 5 \%} \text { CI) }\end{array}$ & $\begin{array}{c}\text { DOR } \\
(\mathbf{9 5 \%} \text { CI) }\end{array}$ \\
\hline Lipocalin 2 (ng/ml) & 221.3 & $\begin{array}{c}0.98 \\
(0.96-1)\end{array}$ & $\begin{array}{c}0.98 \\
(0.88-1)\end{array}$ & $\begin{array}{c}0.91 \\
(0.88-0.94)\end{array}$ & $\begin{array}{c}453.2 \\
(59.9-3426.3)\end{array}$ \\
\hline CSF leukocytes (cell per mm $\left.{ }^{3}\right)$ & 427 & $\begin{array}{c}0.91 \\
(0.86-0.96)\end{array}$ & $\begin{array}{c}0.86 \\
(0.73-0.94)\end{array}$ & $\begin{array}{c}0.8 \\
(0.75-0.84)\end{array}$ & $\begin{array}{c}25.3 \\
(10.2-62.7)\end{array}$ \\
\hline CSF lactate (mmol/L) & 5.8 & $\begin{array}{c}0.95 \\
(0.91-0.98)\end{array}$ & $\begin{array}{c}0.91 \\
(0.79-0.96)\end{array}$ & $\begin{array}{c}0.84 \\
(0.79-0.88)\end{array}$ & $\begin{array}{c}52.5 \\
(17.9-153.5)\end{array}$ \\
\hline CSF/blood glucose ratio & $<0.2$ & $\begin{array}{c}0.78 \\
(0.69-0.86)\end{array}$ & $\begin{array}{c}0.57 \\
(0.42-0.7)\end{array}$ & $\begin{array}{c}0.92 \\
(0.88-0.94)\end{array}$ & $\begin{array}{c}14.3 \\
(6.9-29.4)\end{array}$ \\
\hline CSF protein (g/L) & 2.9 & $\begin{array}{c}0.81 \\
(0.75-0.88)\end{array}$ & $\begin{array}{c}0.57 \\
(0.42-0.7)\end{array}$ & $\begin{array}{c}0.91 \\
(0.87-0.94)\end{array}$ & $\begin{array}{c}13.3 \\
(6.5-27.2)\end{array}$ \\
\hline $\begin{array}{l}\text { CSF white cell count+lactate+CSF/blood } \\
\text { glucose level+CSF protein }\end{array}$ & NA & $\begin{array}{c}0.97 \\
(0.95-1)\end{array}$ & $\begin{array}{c}0.93 \\
(0.82-0.98)\end{array}$ & $\begin{array}{c}0.92 \\
(0.88-0.94)\end{array}$ & $\begin{array}{c}148.2 \\
(42.8-512.8)\end{array}$ \\
\hline $\begin{array}{l}\text { CSF white cell count+lactate+CSF/blood } \\
\text { glucose level+CSF protein+lipocalin 2 }\end{array}$ & NA & $\begin{array}{c}0.99 \\
(0.98-1)\end{array}$ & $\begin{array}{c}0.93 \\
(0.82-0.98)\end{array}$ & $\begin{array}{c}0.97 \\
(0.94-0.98)\end{array}$ & $\begin{array}{c}435.8 \\
(113.3-1676.1)\end{array}$ \\
\hline
\end{tabular}




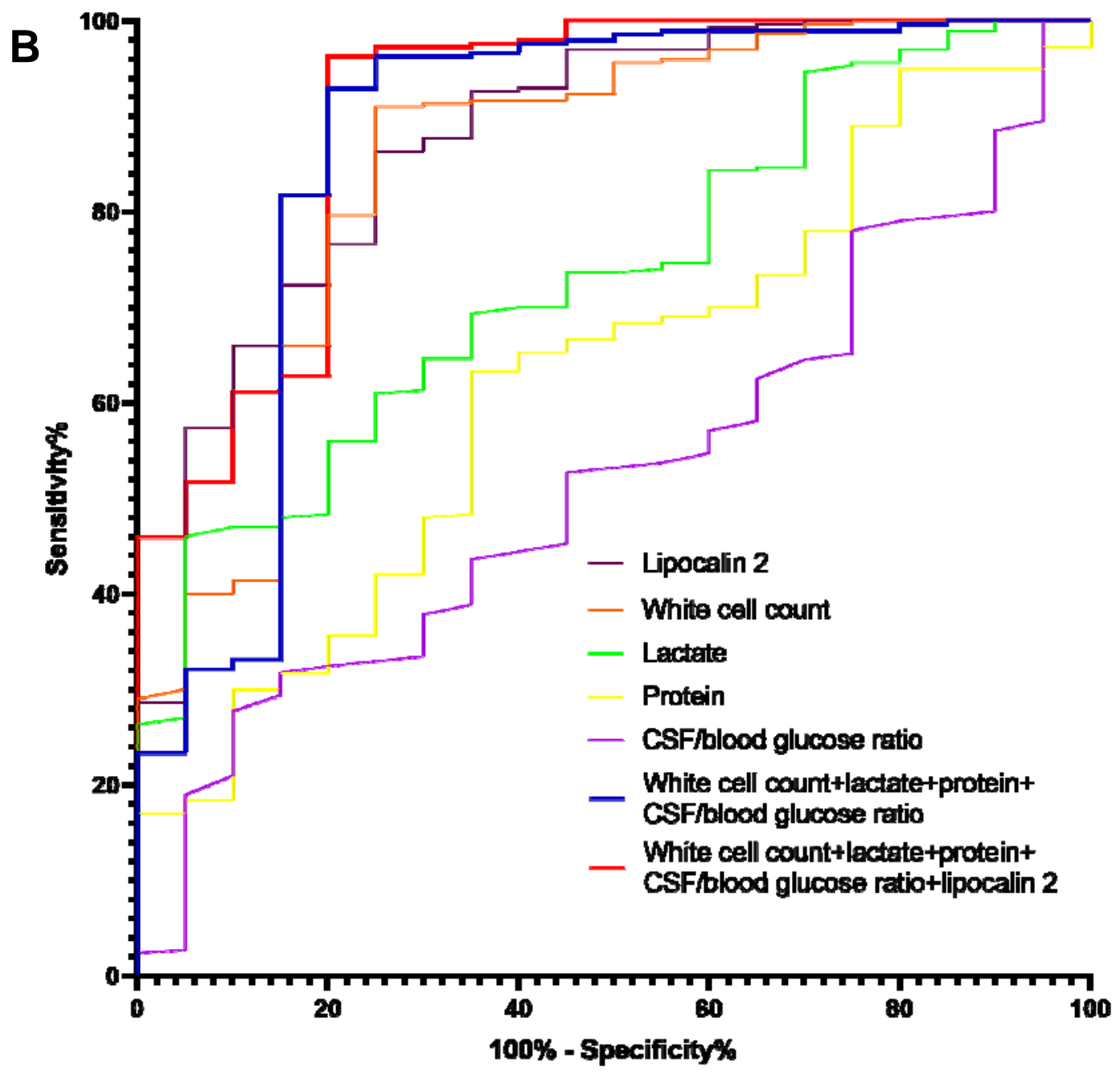

\begin{tabular}{|c|c|c|c|c|c|}
\hline sBM prediction & $\begin{array}{l}\text { Cut-off } \\
\text { values }\end{array}$ & $\begin{array}{c}\text { AUC } \\
(95 \% \mathrm{CI})\end{array}$ & $\begin{array}{l}\text { Sensitivity } \\
(95 \% \text { CI })\end{array}$ & $\begin{array}{l}\text { Specificity } \\
95 \% \text { CI) }\end{array}$ & $\begin{array}{c}\text { DOR } \\
(95 \% \mathrm{CI})\end{array}$ \\
\hline Lipocalin 2 (ng/ml) & 146.5 & $\begin{array}{c}0.88 \\
(0.79-0.96) \\
\end{array}$ & $\begin{array}{c}0.75 \\
(0.53-0.89) \\
\end{array}$ & $\begin{array}{c}0.86 \\
(0.82-0.9) \\
\end{array}$ & $\begin{array}{c}18.9 \\
(6.5-54.9) \\
\end{array}$ \\
\hline CSF white cell count (per $\mathrm{mm}^{3}$ ) & 709 & $\begin{array}{c}0.85 \\
(0.75-0.95) \\
\end{array}$ & $\begin{array}{c}0.75 \\
(0.53-0.89) \\
\end{array}$ & $\begin{array}{c}0.91 \\
(0.87-0.94)\end{array}$ & $\begin{array}{c}30.3 \\
(10.2-89.9)\end{array}$ \\
\hline CSF lactate (mmol/L) & 3.0 & $\begin{array}{c}0.73 \\
(0.64-0.83) \\
\end{array}$ & $\begin{array}{c}0.95 \\
(0.76-0.99) \\
\end{array}$ & $\begin{array}{c}0.46 \\
(0.41-0.52) \\
\end{array}$ & $\begin{array}{c}16.2 \\
(2.1-122.5) \\
\end{array}$ \\
\hline CSF/blood glucose ratio & $<0.7$ & $\begin{array}{c}0.52 \\
(0.41-0.64) \\
\end{array}$ & $\begin{array}{c}0.9 \\
(0.7-0.97) \\
\end{array}$ & $\begin{array}{c}0.28 \\
(0.24-0.34) \\
\end{array}$ & $\begin{array}{c}3.6 \\
(0.8-15.7) \\
\end{array}$ \\
\hline CSF protein $(\mathrm{g} / \mathrm{L})$ & 1.2 & $\begin{array}{c}0.62 \\
(0.51-0.74)\end{array}$ & $\begin{array}{c}0.65 \\
(0.43-0.82)\end{array}$ & $\begin{array}{c}0.63 \\
(0.58-0.69)\end{array}$ & $\begin{array}{c}3.2 \\
(1.2-8.3)\end{array}$ \\
\hline $\begin{array}{l}\text { CSF white cell count+lactate+CSF/blood glucose } \\
\text { level+CSF protein }\end{array}$ & NA & $\begin{array}{c}0.87 \\
(0.76-0.98)\end{array}$ & $\begin{array}{c}0.8 \\
(0.58-0.92)\end{array}$ & $\begin{array}{c}0.93 \\
(0.89-0.95)\end{array}$ & $\begin{array}{c}52.4 \\
(16.1-170.8)\end{array}$ \\
\hline $\begin{array}{l}\text { CSF white cell count+lactate+CSF/blood glucose } \\
\text { level+CSF protein+lipocalin } 2\end{array}$ & NA & $\begin{array}{c}0.9 \\
(0.83-0.98)\end{array}$ & $\begin{array}{c}0.8 \\
(0.58-0.92)\end{array}$ & $\begin{array}{c}0.96 \\
(0.94-0.98)\end{array}$ & $\begin{array}{c}103.6 \\
(29.7-361.8)\end{array}$ \\
\hline
\end{tabular}

Figure S2. Diagnostic performance of LCN2 in discriminating between laboratory confirmed (A) or clinically suspected bacterial meningitis patients $(B)$ and other clinical entities and in comparison with existing biomarkers.

Note to Figure S2: NA: not applicable 